\title{
On the decision to go public: Evidence from privately-held firms ${ }^{\dagger}$
}

\author{
Ekkehart Boehmer \\ Texas A\&M University \\ Mays Business School \\ 306 L Wehner Building \\ College Station, TX 77845 \\ eboehmer@cgsb.tamu.edu
}

\author{
Alexander Ljungqvist \\ New York University, and CEPR \\ Stern School of Business \\ 44 West Fourth Street, \#9-160 \\ New York, NY 10012-1126 \\ aljungqv@stern.nyu.edu
}

\begin{abstract}
We test recent theories of when companies go public which predict that 1) more companies will go public when outside valuations are high or have increased, 2) companies prefer going public when uncertainty about their future profitability is high, and 3) firms whose controlling shareholders enjoy large private benefits of control are less likely to go public. Our analysis tracks a set of 330 privatelyheld German firms which between 1984 and 1995 announced their intention to go public to see whether, when, and how they subsequently sold equity to outside investors. Controlling for private benefits, we find that the likelihood of firms completing an initial public offering increases in the firm's investment opportunities and valuations. We also show that these effects are distinct from factors that increase firms' demand for outside capital more generally.
\end{abstract}

Key words: Going public decision; IPO timing; Private benefits; Family firms. JEL classifications: G32.

Draft: February 12, 2004

\footnotetext{
${ }^{\dagger}$ We are grateful to Yakov Amihud, Pat Fishe, Thomas Hellmann, Jean Helwege, Scott Lee, Colin Mayer, Lubos Pastor, Rafael Repullo, Jonathan Sokobin, Luigi Zingales, two anonymous referees, and seminar participants at New York University, the 2000 NYSE-CEPR Workshop on Primary Equity Markets (Capri), and the 1999 Meeting of the Corporate Group (Venice) for helpful comments. We gratefully acknowledge receipt of the 2002 CDC Award for Best Working Paper in Finance at NYU. Boehmer received financial support from the German Science Foundation (DFG) and the Heisenberg Fellowship.
} 


\title{
On the decision to go public: Evidence from privately-held firms
}

\begin{abstract}
We test recent theories of when companies go public which predict that 1) more companies will go public when outside valuations are high or have increased, 2) companies prefer going public when uncertainty about their future profitability is high, and 3) firms whose controlling shareholders enjoy large private benefits of control are less likely to go public. Our analysis tracks a set of 330 privately-held German firms which between 1984 and 1995 announced their intention to go public to see whether, when, and how they subsequently sold equity to outside investors. Controlling for private benefits, we find that the likelihood of firms completing an initial public offering increases in the firm's investment opportunities and valuations. We also show that these effects are distinct from factors that increase firms' demand for outside capital more generally.
\end{abstract}

Key words: Going public decision; IPO timing; Private benefits; Family firms. JEL classification: G32.

Draft: February 12, 2004 


\section{Introduction}

What determines when companies go public? Idiosyncratic life-cycle considerations no doubt influence the decision whether to go public, and there is a rich theoretical literature modeling a variety of possible trade-offs bearing on this decision. But the fact that aggregate IPO volume tends to fluctuate enormously from year to year suggests that the decision when to go public is at least partly influenced by changes in market conditions, such as changes in valuations and investment opportunities.

We test recent theories of the IPO timing decision that stress the role of changes in valuations and investment opportunities. The key predictions of these theories are that 1) more companies will go public when outside valuations are high or have increased, 2) companies prefer going public when uncertainty about their future profitability is high, and 3) firms whose controlling shareholders enjoy large private benefits of control are less likely to go public.

Our empirical analysis tracks a set of 330 private German firms that between 1984 and 1995 announced their intention to go public in the short- or medium-term. We follow these firms over time, observing whether, when, and how they sell equity to outside investors. By December 1999, the end of our sampling period, $62.7 \%$ of the sample firms had gone public, $13.6 \%$ had raised equity from private sources (typically another company), and 23.6\% remained private without having raised outside equity. Controlling for right-censoring induced by the fact that firms that remain private as of December 1999 might still go public in the future, the average sample company took more than two years from announcing its IPO intention to actually going public. Importantly, there is substantial cross-sectional variation in the time-to-IPO. We use hazard models, which are often used to study questions involving the passage of time before a certain event occurs, to relate this variation to the factors suggested by theory.

Our key results can be summarized as follows. Post-announcement improvements in a firm's sales or earnings growth and in its profit margins (relative to other firms in its industry) increase the likelihood of going public, on the order of $14 \%$ for a one standard-deviation increase in each of 
these firm-level value drivers. More favorable conditions in the wider economy and higher stock market returns in the firm's industry have the largest impact, each increasing the likelihood of completing an IPO by around a third for a one standard-deviation increase. Firms are $25 \%$ less likely to go public when IPO activity increases by one standard deviation, suggesting the presence of bottlenecks or capital constraints in Germany's relatively underdeveloped IPO market. We also find some evidence of the predicted positive relation between uncertainty and IPO timing, although it is generally not significant. Finally, among the 330 firms that had announced their intention to go public, family firms - which arguably are more concerned about maintaining private benefits of control - are $26 \%$ less likely than other firms to go public at a given point in time. These effects are distinct from factors that increase firms' demand for outside capital more generally, in the sense that they cannot explain the decision to raise equity privately instead of going public.

Our results are consistent with recent work by Benninga, Helmantel, and Sarig (2003) (henceforth BHS). In their model, the entrepreneur at each point in time chooses between selling equity to well diversified outside investors and remaining private. The trade-off is between the higher valuations diversified outside investors are willing to pay (from which the entrepreneur only benefits when the firm is public), and private benefits of control (which he only enjoys when the firm is private). Ceteris paribus, as long as the entrepreneur's private benefits exceed the cost of being under-diversified, he will choose to remain private. Outside investors' valuations (and thus the cost of under-diversification) vary over time as market conditions and the firm's cash flows and prospects change, and therefore so does the case for going public.

Pastor and Veronesi (2003a) also study the timing of IPOs but emphasize the importance of changes in valuations (as captured by returns) rather than valuation levels (say, a high market-tobook ratio in the industry). All else equal, firms are more likely to go public following recent improvements in market conditions, regardless of the level of valuations in the market. We find that recent returns matter more than the level of market-to-book ratios, which supports this emphasis on 
changes rather than levels. Pastor and Veronesi further predict that more firms go public when uncertainty about their future profitability is high. The intuition builds on Pastor and Veronesi's (2003b) insight that valuations increase in uncertainty about the growth rate in profits, due to the convex relation between growth rates and terminal values.

The existing literature on IPO timing focuses on the aggregate time series behaviour of IPO volume. Lowry (2003) studies the time series of IPOs in the U.S., showing that the main determinants of fluctuations in IPO volume are changes in firms' demand for outside capital and proxies for investor sentiment. Helwege and Liang (2004) argue that firms going public in periods of high IPO volume do not differ in any key characteristic from those going public in low volume periods. Cook and Kieschnick (2003) document that IPO volume increases in industry profitability, stock valuations, and a measure of the value of control rights. Pastor and Veronesi (2003a) find that 'IPO waves' coincide with peaks in stock market returns, increases in aggregate profitability, positive revisions to analysts' long-term earnings growth forecasts, and higher volatility.

Our cross-sectional analysis of the time-to-IPO complements these studies by showing that firmlevel changes in valuations and market conditions affect firms' subsequent decisions to go public. The existence of a clear time line of events in our data increases our confidence in interpreting these empirical relations as causal.

Our study is related to a small but growing literature on why companies go public. Pagano, Panetta, and Zingales (1998) examine why private firms in Italy go public. Their results suggest that company size and, especially, the industry's market-to-book ratio increase the likelihood of a company going public. Helwege and Packer (2003) use an unusual but interesting sample of private firms (those that file with the S.E.C., usually because they have issued public bonds) and show that they are more likely to go public if they have private equity investors. This supports Black and Gilson's (1998) view that stock market listings provide an exit opportunity for professional pre-IPO investors. Also using U.S. data, Brau, Francis, and Kohers (2003) examine the choice between an 
IPO and selling the firm to a publicly traded buyer, conditional on wishing to sell the company. (That is, they have no data on companies that stay private.) Private firms are more likely to choose the IPO route over a takeover, the larger their transaction size and the lower the market-to-book ratio in their industry.

Our sampling strategy is somewhat unusual in that it focuses on companies that have revealed a preference for going public. Since we have no data on private firms that did not intend to go public, we cannot say anything about what causes a firm to announce an IPO plan in the first place. This selection aspect implies that, say, a simple probit comparing sample firms that eventually did go public to those that did not is likely to be biased. Instead, the power of our tests derives from the fact that we observe a set of companies over time. This time dimension enables us to study how postannouncement changes in company characteristics and external conditions influence the decision to go ahead with an IPO, conditional on having announced an intention to go public in principle.

Our focus on German firms also deserves comment. Certain characteristics of Germany, its corporate sector, and its capital markets make this country a promising laboratory within which to study the determinants of the going public decision. ${ }^{1}$ First, at least over our sample period, Germany's capital markets for private (VC) and public (IPO) equity were relatively less developed than those in the U.S. ${ }^{2}$ For instance, the market for underwriter services was highly concentrated and probably not very competitive. By implication, the higher frictional costs of going public in Germany required greater offsetting benefits to trigger the going-public decision. From the econometrician's perspective, this improves our chances of isolating the determinants of the decision in the data.

Second, because IPOs were still something of a novelty in Germany over much of our sample period, announcements of IPO intentions attracted a great deal of media interest. The resulting

\footnotetext{
${ }^{1}$ Many of these characteristics apply equally to other European countries, with the exception of the United Kingdom. In this respect, we view Germany as representative of Continental Europe.

${ }^{2}$ The number of exchange-listed firms in Germany in 1994 was 666, compared to 7,684 in the U.S. Over the 35 years to 1994, there were about 200 IPOs in Germany, compared to more than 10,000 in the U.S.
} 
media coverage, both at announcement and subsequently, enables us to gather comprehensive data on a set of private companies that would normally be hidden from public view. These data include both 'hard' information on financials and ownership and 'soft' information such as management statements containing details of the going public decision.

Third, German firms have traditionally relied more on bank finance than on external equity (say from venture capitalists), and scholars of comparative financial systems routinely ascribe this to strong preferences for the preservation of private benefits of control (e.g. Franks and Mayer (2001)), in the context of relatively weak legal protection for minority shareholders (La Porta, Lopes-deSilanes, and Shleifer (1999), Volpin (2000)). Empirical studies suggest that private benefits of control, a key ingredient of the BHS model of IPO timing, are five to ten times more important in Germany than in the U.S. (Dyck and Zingales (2002), Nenova (2003))..

Finally, Germany is unusual in that a fairly systematic record of IPO announcements exists, and in that such announcements occur at an early stage in the process. The U.S., by contrast, has no systematic record of IPO announcements. It is true that U.S. firms' S.E.C. registrations are easily observable. But the short time between registration and IPO (averaging 3.9 months, compared to the two years or more that elapse between announcement and IPO in Germany) ${ }^{3}$ prevents us from observing U.S. companies while they await the right time to go public. Effectively, a cross-sectional dataset of U.S. IPOs would suffer from what is called left-censoring.

The remainder of the paper is organized as follows. We develop our empirical model in Section 2, with particular focus on our proxies for outside valuations and private benefits. Since our dataset is new, Section 3 describes its salient features in some detail. In Section 4, we report our main tests of the determinants of firms' decisions to go public. Section 5 concludes.

\footnotetext{
${ }^{3}$ The estimate for the U.S. is based on a sample of 6,181 completed and 1,422 withdrawn IPOs between 1985 and 2000 , and is corrected for the right-censoring caused by IPO withdrawals. See Benveniste, Ljungqvist, Wilhelm, and Yu (2003) for details on the sample construction.
} 


\section{The empirical model}

There is a large theoretical literature on why companies go public. ${ }^{4,5}$ While stressing different trade-offs, these models have in common that they are essentially static, in that they leave little room for entrepreneurs to 'time' their IPOs, depending on the state of the economy, industry, of IPO market. As these conditions change over time, one would expect entrepreneurs to periodically reevaluate whether to stay private or go public.

BHS model the decision to go public as a trade-off between the benefit of the higher valuations outside investors are willing to pay and the cost to the entrepreneur of having to give up his private benefits of control once the company has gone public. While private benefits are assumed to stay constant, outside investors' valuations vary over time. Pastor and Veronesi (2003a) link IPO timing to changes in market conditions, so we will control for outside valuations both in levels and first differences. In addition, they predict that the probability of going public increases in uncertainty about the firm's future profitability. In sum, we obtain the following empirical model of the IPO decision:

$\operatorname{Pr}($ firm $i$ goes public at time $t)=f($ private benefits, outside valuations, $\Delta_{t}$ outside valuations, uncertainty $y_{t}$, controls)

Note that the dependent variable and some of the independent variables are time-varying, so that the model in (1) cannot be estimated using standard logit or probit techniques. Instead, the

\footnotetext{
${ }^{4}$ One branch of the literature stresses firm-specific benefits, such as the need to raise capital for investment purposes (Welch (1989)); the need to provide an exit for the founder (Zingales (1995), Mello and Parsons (1998), Stoughton and Zechner (1998)); the need to provide an exit for the company's venture capital backers (Black and Gilson (1998)); diversifying the founding shareholders' wealth (Leland and Pyle (1977)); reductions in the cost of capital due to greater liquidity (Amihud and Mendelson (1988)); or scale economies in the costs investors incur when evaluating the company's prospects (Chemmanur and Fulghieri (1999), Subrahmanyam and Titman (1999)). Another branch of the literature focuses on the informational benefits public trading can provide, in the form of better estimates of the merit of planned investments (Benveniste and Spindt (1989), Dow and Gorton (1997), Subrahmanyam and Titman (1999), Maug (2001)) or improved monitoring of managers (Pagano and Röell (1998), Holmström and Tirole (1993), Bolton and von Thadden (1998)).

${ }^{5}$ Röell (1996) provides an overview of field-based studies and highlights three key reasons why companies go public: trading liquidity which increases the effectiveness of employee incentive schemes; the role of share prices in conveying information about a company's prospects to customers, suppliers, employees and potential providers of finance; and the potential for access to outside capital on more competitive terms.
} 
problem lends itself naturally to so called hazard analysis. ${ }^{6}$ The hazard function $h(t)$ is the instantaneous rate of an event (here: going public) occurring at time $t$. Formally, it is the limiting probability that the firm will go public in a given time interval conditional on it not yet having gone public by the beginning of the interval as the width of the interval goes to zero. This can easily be parameterized as a function of a set of determinants $\mathrm{X}_{t}$ (such as outside valuations): $h_{i}(t)=g\left(t, x_{i t} \beta\right)$. In Section 4, we will discuss suitable functional forms for the relation between the hazard, time, and the $\mathrm{X}_{t}$ variables. In the remainder of this section, we motivate our choice of proxies for outside valuations and private benefits, both of which are unobservable. A detailed discussion of the sample and data sources follows in Section 3.

\subsection{Outside valuations}

Studies of traded securities benefit from publicly observable valuation data that are necessarily unavailable for our set of private firms. Instead, we take a hedonic approach which assumes that a firm's outside valuation increases in its performance and profitability, investment opportunities, and macroeconomic conditions, controlling for uncertainty about the firm's future profitability and conditions in the debt and IPO markets.

\subsubsection{Firm-level data}

Private firms in Germany do not typically publish financial statements, so obtaining firm-level information is an elaborate process. ${ }^{7}$ We conduct an extensive search of press reports and a variety of databases, beginning three years before each company's IPO announcement and ending three years after the final decision (or December 1999, whichever is earlier). The two value drivers we focus on are sales and earnings. In our empirical model, we control for both the levels effect highlighted by BHS (using net profit margins, i.e. return on sales) and the first differences effect

\footnotetext{
${ }^{6}$ Examples of hazard analysis in financial economics include Hellmann and Puri (2000) who model the time it takes a start-up firm to obtain venture capital; and Ongena and Smith (2001) who examine the duration of bank lending relationships.

${ }^{7}$ Technically, all corporations are required to file annual reports with a local court, and to publish extracts in a nationwide newspaper. This regulation, however, was not systematically enforced during our sample period.
} 
emphasized by Pastor and Veronesi (2003a) (using sales growth and earnings growth). We normalize all three variables by the corresponding numbers for the median company in the same industry to isolate the IPO candidate's own idiosyncratic value drivers.

Zingales (1995) argues that the value of control rights is harder to establish than the value of cash flow rights. Thus, when companies solely intend to raise new capital, their equity should be easier to value than when they (also) intend to sell claims on the existing equity. Companies intending to sell existing stock should thus require a larger offsetting benefit before proceeding with the IPO. All else equal, we hence expect such companies to be less likely to complete an IPO, or equivalently to take longer to do so. To operationalize this control variable, we identify each firm's self-declared reason for seeking to go public.

\subsubsection{Market valuations and investment opportunities}

Improvements in investment opportunities should increase outside investors' valuation. To proxy for investment opportunities, we construct an annual time series of market-to-book ratios at the industry level. Pastor and Veronesi (2003a) suggest that valuation levels should matter less than changes in valuations, that is, recent stock returns. Consistent with this suggestion, previous studies have documented a link between prior returns and the likelihood and volume of public equity being raised. Choe, Masulis, and Nanda (1993) find that already-listed firms raise more equity in bull markets, while Lerner (1994) documents that VC-backed biotech companies go public following unusually high returns on a biotech index. To capture this effect, we compute stock index returns at the industry level.

\subsubsection{Proxies for uncertainty about future profitability}

To capture Pastor and Veronesi's (2003a) prediction that firms prefer going public when uncertainty about their future profitability is high, we employ two proxies. The first is company age at the time of the original IPO announcement. In Pastor and Veronesi's model, uncertainty declines over time due to learning. Thus younger companies pose a greater valuation problem, all else equal. 
The second proxy is measured at the industry level, using the volatility of stock returns in the sample firm's industry.

\subsubsection{Macroeconomic conditions}

Changes in macroeconomic conditions plausibly affect a company's future prospects and thus its valuation. There is a wide range of possible variables to choose from, including GDP growth, capacity utilization, or the leading indicators published by Ifo, an economic research institute at the University of Munich. Not surprisingly, these are highly correlated. In practice, we find macroeconomic conditions to have little effect on IPO timing, with the exception of consumer confidence.

\subsubsection{Conditions in the debt and IPO markets}

Increases in the cost of debt capital make raising equity relatively more attractive. Meaningful firm-specific or even industry-level estimates of the cost of debt are hard if not impossible to find in Germany. Instead, we approximate conditions in the debt market using the average risk premium of corporate bonds. This is defined as the Bundesbank's estimate of the corporate bond yield premium over FIBOR, the Frankfurt Inter-Bank Offered Rate.

Prior literature suggests conditions in the IPO market may indirectly capture investor valuations and thus influence the relative attractiveness of going public. Using U.S. data, Lowry and Schwert (2002) show that following periods of high underpricing, more firms file IPO registrations with the S.E.C., firms already in registration accelerate their IPO plans, and fewer IPOs are cancelled. This suggests that higher-than-expected underpricing may indicate that investors value IPO companies more highly than the companies and their advisors had anticipated. This makes going public more attractive, assuming later issuers can respond by pricing their offerings more aggressively.

High IPO volume has an ambiguous effect on the attractiveness of going public. On the one hand, high volume may indicate a sustained 'hot' market worth taking advantage of (Ritter (1984)). On the other hand, high volume may increase the cost of going public: when the IPO calendar is 
crowded, underwriters may offer less attractive terms (Altinkilic and Hansen (2000)). This would be true if underwriting capacity was in relatively fixed supply in the short run, which is plausible in Germany where (during our period of study) few banks had underwriting operations of any significant size.

\subsection{Private benefits}

An important aspect of the BHS model is that the entrepreneur compares outside valuations to his private benefits. In their model, private benefits are constant over time and so not affected by changes in the firm's performance or environment. This assumption is helpful in designing the empirical model because private benefits are unobservable in practice. There is a growing body of evidence that suggests that private benefits play a greater role among family firms than among companies controlled by corporations, such as subsidiaries that are being prepared for spin-offs (see Burkart, Panunzi, and Shleifer (2003), Anderson, Mansi, and Reeb (2003), and others). We therefore assemble a careful picture of each firm's ownership structure at the time of the IPO announcement, and determine whether it is majority-owned by a family. ${ }^{8}$

\section{The sample}

\subsection{Sample construction}

Before 1983, IPOs were extremely rare in Germany, averaging fewer than one a year. In 1983, nine companies went public starting what commentators at the time called Germany's 'IPO wave.' The resulting media interest shone a spotlight on companies that were preparing to go public, and from June 1984, Börsen-Zeitung, a quasi-official newspaper associated with the Frankfurt Stock Exchange, began to publish a list of IPO announcements. ${ }^{9}$ We refer to firms making such

\footnotetext{
${ }^{8}$ In a previous draft, we also characterized the presence of outside minority blocks of less than $25 \%$. However, we are no longer confident that this information is available for all firms on a systematic basis, since privately-held companies are not required to disclose such ownership stakes. As a result, we are unable to systematically identify pre-IPO equity stakes held by venture capitalists, a potentially important group of shareholders.

${ }^{9}$ In the U.S., firms wishing to sell shares to the public must register with the S.E.C. There is no equivalent registration in Germany, though companies must apply to their chosen stock exchange for permission to list. Disclosure of such applications is voluntary, so there is no publicly observed 'filing date'.
} 
announcements as IPO candidates. Announcements potentially cover all eight exchanges in

Germany as well as all market segments (official trading, the regulated market, and the free market), though usually firms do not provide detailed information about where they intend to list. ${ }^{10}$ Between June 1984 and December 1995, 311 firms appeared on the Börsen-Zeitung list. Over that period, the microstructure of Germany’s IPO market remained largely unchanged. ${ }^{11}$

Börsen-Zeitung does not disclose its criteria for including companies in the list, and the people responsible for compiling the list over our sample period are no longer available for comment, but there are clues. In late 1986, for example, an editorial commented that certain firms, rumored to be considering going public, were not yet included due to the vagueness of the rumors. In August 1987, Börsen-Zeitung stated as the reason for dropping a number of companies private correspondence from the companies denying they intended to raise equity. Both of these clues suggest a minimum 'seriousness threshold' for inclusion in the list. Still, the list could be subject to two biases. First, it could be under-representative in the sense of omitting bona fide IPO candidates. Second, it could be over-inclusive in the sense of including firms merely because of newspaper speculation, as opposed to company announcements.

We investigate each potential bias using news sources provided on-line in Nexis-Lexis, DowJones News Retrieval, and Reuters Business Briefing (now Factiva) as well as hardcopy sources in newspaper archives. ${ }^{12}$ First, we search for omitted IPO candidates and identify 53 additional potential cases. In 18 of these, the IPO was announced and completed between two list publication

\footnotetext{
${ }^{10}$ Listing requirements vary by market segment. The most stringent requirements apply to official trading. The expected market capitalization must be at least DEM 2.5 million, the issuing company must have been in existence for at least three years, and a minimum of $25 \%$ of outstanding shares must be offered to outside investors. Most of our companies satisfy the first two requirements, while the third requirement is endogenous.

${ }^{11}$ Two subsequent regime changes contributed to a more active IPO market in 1998-2000. In 1995, bookbuilding techniques were imported from the U.S. These have now virtually replaced fixed-price offerings (see Ljungqvist, Jenkinson, and Wilhelm (2003)). In March 1997, the Frankfurt Stock Exchange launched a new market segment for smaller, mostly high-tech companies, the Neuer Markt. Our IPO announcements precede both of these developments. ${ }^{12}$ The online sources cover all the main national newspapers (Börsen-Zeitung, Handelsblatt, Frankfurter Allgemeine Zeitung, Süddeutsche Zeitung, and so on), wire services (notably Reuters and Dow Jones), business and trade magazines, and press releases. The news archive at the Hamburg Institute of International Economics (HWWA) consists of news clippings organized by company name.
} 
dates, which may be why Börsen-Zeitung failed to include them. Another 18 IPO announcements (later postponed) were omitted by Börsen-Zeitung for no apparent reason. The final 17 cases turn out to be newspaper speculation, rather than verifiable company announcements. For example, a journalist might speculate that firm $\mathrm{ABC}$ may become interested in going public following the IPO of its main competitor. We add the 36 verified IPO announcements but not the 17 speculative cases to our dataset, giving a sample of 347 firms.

Over-inclusion bias does not appear to be a problem: we find only six firms on the BörsenZeitung list whose IPO intentions we cannot confirm from other sources. We exclude these, along with nine Unternehmensbeteiligungsgesellschaften (closed-end investment companies required by law to float $70 \%$ of their equity within ten years of incorporation) and two firms that had previously been listed. This gives a final sample of 330 IPO candidates. Figure 1 shows the number of IPO announcements by year. The annual number of announcements ranges from 16 to 43, with peaks in 1986 and 1990.

Based on the news stories, company reports, and information from Worldscope, we assign the 330 sample companies to the 12 industries covered by the DAFOX family of stock market indices. ${ }^{13}$ Table 1 provides the resulting industry breakdown of our sample. The firms are drawn from a wide range of sectors, most of which are fairly traditional (e.g. machine tools, construction). This is markedly different from the U.S., where IPO companies tend to come from high-tech or nascent industries. Note that our sample period precedes the Internet IPO wave of the late 1990s. The largest industry group, accounting for $29.1 \%$ of our sample, is 'Consumer goods, food, breweries, paper, and entertainment'.

\subsection{Subsequent choices}

For each of the 330 sample firms, we read every news article available in Nexis, Dow-Jones, or

\footnotetext{
${ }^{13}$ The DAFOX indices cover all officially listed German companies, accounting for more than $90 \%$ of market capitalization. They are thus considerably broader than the better-known DAX index of the 30 leading shares. Unlike the DAX, the DAFOX indices are computed according to consistent rules that ensure comparability over time. For further information (in German), see http://finance.wiwi.uni-karlsruhe.de/Forschung/dafox.html.
} 
Reuters to determine the outcome of its IPO plan. By December 1999, 207 companies (62.7\%) had gone public, ${ }^{14}$ while $123(37.3 \%)$ remained private. Among the latter, $45(13.6 \%)$ raised equity from private sources. This includes 19 firms that sold the entire company, eight that sold a majority stake to an outside investor, nine that sold a non-controlling stake (of between $25 \%$ and $50 \%$ ), and nine that sold less than $25 \%$ (including firms that raised capital through joint ventures or privately sold so called 'participation rights'). Note that the buyers were typically other corporations or sometimes banks, rather than venture capital investors. The remaining 78 firms $(23.6 \%)$ had raised no outside equity from any source by December 1999. Together, the 123 companies that did not go public by December 1999 are deemed right-censored, in the sense that there is a positive probability that they may yet go public in the future.

We will refer to the firms that opted for an IPO as 'public sellers', those which sold equity privately as 'private sellers', and the remainder as the 'residual group'. As a first step in understanding why private sellers and firms in the residual group did not go public, we search company announcements and news articles for self-reported reasons. Table 2 shows that about a third of the 123 companies blamed their withdrawal on 'poor company performance' postannouncement. In fact, $11 \%$ experienced outright financial distress (bankruptcy, liquidation, etc.). This includes five companies that were restructured following sale to new investors, and eight companies in the residual group that were liquidated following bankruptcy.

Typically, firms withdrew at a very early stage in the IPO process, generally even before concrete details of the offering became available. ${ }^{15}$ In fact, only one company abandoned its IPO in the final stages of the IPO process, days before the official start of trading. Our sample thus differs

\footnotetext{
${ }^{14}$ All but one of these went public on one (or occasionally more) of Germany's eight exchanges. The exception is Qiagen, which went public on Nasdaq. A further three companies obtained dual listings in Germany and another country.

${ }^{15}$ Just under a third of the sample firms got no further than to announce their intention to go public. A further sixth abandoned their IPO plans when they either already had bank support, or were in the process of negotiating with a bank. The remaining $58 \%$ had either put in place the necessary legal requirements (such as a change in corporate form and structure) or announced specific details of their IPO plans when pulling out.
} 
considerably from the cohort of U.S. IPO candidates studied by Busaba, Benveniste, and Guo (2001), which tend to withdraw after marketing their stock to potential investors. ${ }^{16}$

The average (median) public seller took 422 (182) days from announcing its IPO intention to the start of exchange trading. However, this estimate is downward biased because it ignores that companies that are still private as of the end of December 1999 may still go public in the future. Adjusting for right-censoring, the average (median) company spends 868 (456) days in our sample. There is substantial cross-sectional variation in the time companies take to go public, and in Section 4, we will model the determinants of when firms decide to go public.

\subsection{Firm-specific value drivers}

\subsubsection{Performance}

We face the practical problem that financial data on privately-held companies in Germany are difficult to obtain, partly because of their general reluctance to disclose 'sensitive' information, and partly because standard sources - we use Hoppenstedt (Handbuch der Aktiengesellschaften, Handbuch der Großunternehmen, and Handbuch der mittelständischen Unternehmen), Thomson Financial's Worldscope, and the collection of IPO prospectuses and annual reports available on Thomson Financial's Global Access service - tend to focus on much larger companies than those in our sample. Luckily, our sample companies appear unusually willing to disclose at least sales and earnings figures to the business press, especially after the IPO announcement. ${ }^{17}$

Table 3 reports descriptive statistics on company performance and profitability for each of the three years before the IPO announcement and in year 0 (the fiscal year in which the announcement is made), as well as company age at announcement. For the sample as a whole, the median sample

\footnotetext{
${ }^{16}$ Within the context of bookbuilding theories, Busaba et al. (2001) argue that firms use the threat to withdraw from the IPO process at the last moment to ensure better-informed investors reveal their pricing-relevant information truthfully when bidding into the underwriter's 'book'. In Germany, bookbuilding came into use only in 1995.

${ }^{17}$ Given our focus on private companies, we do not have the luxury of standardized accounting data. While our companies tend not to change the type of accounting data they disclose from year to year, the definition of these variables can vary in the cross-section. For example, reported sales figures could be more or less consolidated, while reported earnings could be before or after tax, depreciation and so on. Because much of our analysis, and especially the hazard models in Section 4, relies on the time dimension, we always ensure that variables are measured consistently over time. Most data points are in fact consolidated sales and EBITDA earnings.
} 
company in year 0 had sales of DEM 224.9 million and earnings of DEM 7.3 million. (Monetary figures are reported in constant 1991 Deutsche Mark. Over the sample period, the exchange rate fluctuated between 1.353 DEM/\$ and 3.455 DEM/\$.)

Earnings, and to some extent sales, appear to have grown over the prior three years. To control for more general trends in earnings and sales growth, we adjust growth rates for the median growth in the company's Worldscope industry. (Note that Worldscope covers both public and private companies, and that we use only German companies in computing industry adjustments.) On this basis, our sample companies grew significantly faster than their industries, with annual industryadjusted sales growth for the median firm ranging from $16 \%$ to $23 \%$ in the three years preannouncement. Earnings growth among our sample companies similarly outstripped the industry benchmark.

Comparing the level of earnings across firms of different size can be misleading. Thus we compute returns on sales (net profit margins), adjusted for median profitability in the company's Worldscope industry. Using this measure, sample firms were significantly more profitable than their industries in year 0 , with median ROS of $1.4 \%$ in excess of the industry benchmark.

We also report median company age in the announcement year, based on a variety of sources including the news stories, regulatory filings, company websites, and the files of Creditreform, a credit reference agency. Despite our best efforts, we were unable to find age information for 16 of the 330 sample firms. The median age of 38 years clearly indicates that our sample firms are not small start-ups, unlike the typical IPO firm in the U.S. This mirrors Pagano, Panetta, and Zingales' (1998) findings for Italy.

Table 3 also provides a breakdown of performance and profitability by public and private sellers and the residual group. Looking across the three subsamples in Table 3, we find few differences. Firms in the residual group were larger in year 0 (with median sales of DEM 288 million) than public sellers (DEM 205 million) or private sellers (DEM 188 million). Public sellers had the 
highest level of earnings in year 0, with median earnings of DEM 7.8 million against DEM 4.2 million for the private sellers and DEM 7.2 million for the residual group. All three groups experienced significantly faster sales growth than firms in their Worldscope industries did, but only public sellers saw earnings growth that exceeded the industry benchmark significantly. Public sellers also enjoyed significantly better ROS than their industries. The median public seller had industry-adjusted net margins of $1.4 \%$. Private sellers, on the other hand, performed in line with their industry medians, with a median industry-adjusted net margin of $-0.1 \%$. Finally, public sellers were typically older (48 years) than private sellers (28) or firms in the residual group (25).

\subsubsection{Self-declared IPO reasons}

As argued earlier, when companies solely intend to raise new capital, their equity should be easier to value than when they (also) intend to sell claims on the existing equity (Zingales (1995)). Table 4 outlines the reasons for seeking to go public as stated by the firms themselves at the time of their announcements. Of the 330 sample companies, 132 (40\%) intended to only raise new capital for the company, that is, to sell 'primary' stock. ${ }^{18}$ The remaining 198 firms $(60 \%)$ declared their intention to sell existing ('secondary') stock, possibly in combination with an offer of primary stock. In $10.3 \%$ of cases, corporate owners intended to divest $100 \%$ of their shares (labeled divestitures in the table). Exits by financial institutions such as venture capitalists or banks are rarely cited as the main reason for wishing to go public, at $3.9 \%$ of cases. This reflects the relatively underdeveloped state of Germany's VC industry during our sample period.

\subsection{Proxying for private benefits}

Table 5 characterizes the sample firms' ownership structure at the time of the announcement.

\footnotetext{
${ }^{18}$ Examples of such motivations include "to fund new product development / acquisitions / capital-intensive investments / expansion / the next ten years' growth", "a rapid growth rate", or "a growing need for capital." Typically, the announcement of a primary IPO was coupled with the creation of reserve capital or non-voting shares and the suspension of the existing shareholders' pre-emption rights, both of which are key steps in raising primary equity. Some firms explicitly mentioned capital constraints or the wish to broaden their sources of finance ("to ease capital constraints", "gain access to alternative sources of finance when finding it hard to get credit to fund investment", "improve access to capital", or "widen the financial base").
} 
Ownership data come from newspaper sources, annual reports, and IPO prospectuses, and are both supplemented and cross-checked with standard sources such as Commerzbank's Wer gehört zu wem? and Hoppenstedt's publications. Ownership data are available for 319 firms. Most sample firms are family-controlled: $60 \%$ are majority-controlled by a family, $13.3 \%$ are controlled by another company, $11.2 \%$ are controlled by some other owner (such as a financial institution or a government body), and $12.1 \%$ have no majority owner (including employee-owned firms and cooperatives).

\section{The going-public decision: A dynamic perspective}

Clearly, most sample companies do not go public immediately following the announcement of their IPO plans, and some never go public at all. In this section, we explore how post-announcement changes in firm-level value drivers and external conditions influence when a sample company proceeds with its IPO or, equivalently, the probability that it does so in a given quarter. We begin by describing the evolution of the firm-level value drivers (Section 4.1) and external conditions (Section 4.2) over the first three years after the announcement. We then estimate hazard models to isolate the marginal effects of changes in these variables on a firm's IPO decision (Section 4.3).

\subsection{Post-announcement evolution of firm-level value drivers}

Table 6 reports the evolution of sales and earnings over the three years following the IPO announcement. Of course, the time between announcement and IPO varies across firms in ways the three-year window shown in the table cannot capture. For instance, many firms remain private three years after the announcement. The table is thus merely intended to describe the general evolution of our firm-level value drivers, before moving on to the hazard models in Section 4.3.

Following the announcement, sample firms continue to increase their sales faster than their industry benchmarks, but at a slower rate than before. Indeed, like in the U.S. (Mikkelson, Partch, and Shah (1997)), companies seem to announce their intention to go public at the top of their sales growth cycle: industry-adjusted sales growth for the median sample firm slows from $16.3 \%$ in the 
pre-announcement year to $9.5 \%$ three years later. We observe a similar slow-down in industryadjusted sales growth for both private and public sellers, but it is more pronounced for private sellers whose median sales growth declines from $23.4 \%$ in the announcement year to $2.7 \%$ three years later.

Public sellers are significantly more profitable in the announcement year than are private sellers. This difference persists for the next three years, in terms of both earnings levels and returns on sales. Moreover, while public sellers perform significantly better than their industry peers in terms of earnings growth and return on sales, private sellers perform no better than the industry median.

\subsection{External conditions}

Figures $2 \mathrm{a}$ through $2 \mathrm{~g}$ show the evolution of seven indicators of external conditions, from three years before the IPO announcement to three years after. Each figure shows three graphs: the solid line refers to the median sample firm, while the dashed and dotted lines identify the median public and private seller, respectively.

To proxy for market valuations and investment opportunities, we construct an annual time series of market-to-book ratios at the industry level. Specifically, for every listed German company covered in Thomson Financial's Worldscope Global database, we compute a market-to-book ratio as of the end of each calendar year. We then assign the detailed Worldscope industries to the 12 DAFOX industries that our sample companies are grouped under. Our proxy for investment opportunities in industry $j$ in year $t$ is the median listed company's market-to-book ratio in that industry at the end of year $t$. The median firm announces its intention to go public after sharp increases in its industry's market-to-book ratio (Fig. 2a). Over the next three years, market-to-book ratios stay essentially flat for the sample as whole, though private sellers experience marked declines in market-to-book ratios. These declines might have contributed to their decision to postpone their IPO plans.

IPO announcements are preceded by high stock index returns in the IPO candidate's industry, 
especially in year -1 , which drop off sharply in the following three years (Fig. 2b). This suggests that firms time their IPO announcements to coincide with relative peaks in their industry valuations.

Firms tend to announce IPO plans after increases in the volatility of share prices in their industry (Fig. 2c). This is consistent with Pastor and Veronesi's (2003a) prediction that firms prefer going public when uncertainty about their future profitability is high. The pattern is particularly pronounced among firms that eventually sell equity privately: the standard deviation of daily DAFOX industry-index returns increases from $0.93 \%$ in year -3 to $1.16 \%$ in the announcement year. Over the next three years, it falls back below $1 \%$, while for firms that eventually go public it keeps rising.

Macroeconomic conditions are proxied using a consumer confidence index based on a survey of 2,000 people conducted monthly by GfK, a market research company, on behalf of the European Commission. The GfK index measures consumers' expectations regarding the development of the economy over the next 12 months. Consumer confidence peaks in the median firm's announcement year and then declines sharply (Fig. 2d). The median IPO announcement follows a period of falling yields on corporate debt (Fig. 2e) which stay low over the subsequent three years. Conditions in the IPO market show no obvious patterns: initial underpricing returns are more or less flat in the three years before the announcement and decline somewhat afterwards (Fig. 2f) while the number of IPOs fluctuates in a narrow band between 15 and 18 IPOs per year (Fig. $2 \mathrm{~g}$ ).

\subsection{Hazard analysis}

Table 6 and Figures $2 \mathrm{a}$ through $2 \mathrm{~g}$ suggest, somewhat crudely, that changes over time in the firm-level value drivers and external conditions correlate with firms' final decision whether or not to go public. While this is consistent with the central predictions of BHS and Pastor and Veronesi (2003a), we clearly have not yet carefully captured the dynamics of the decision problem, nor have we exploited the cross-sectional dimension of the data. We now model the IPO timing decision explicitly as a function of our proxies for the time-varying valuation outside investors are willing to 
pay for the company's stock. As outlined in Section 2, we estimate the likelihood (or hazard) $h_{i}(t)$ that a firm $i$ with attributes $x_{i t}$ will go public in the next instant $\Delta t$, given that it has not already done so. (This is isomorphic to modeling the determinants of the time-to-IPO.) Generically, this can be written as $h_{i}(t)=g\left(t, x_{i t} \beta\right)$, but for estimation purposes we need to specify a functional form for the relation between the hazard, time, and the $\mathrm{X}_{t}$ variables.

Most hazard analyses assume that $h(t)$ can be written as the product of a 'baseline hazard' describing how the probability of the event changes over time assuming no exogenous influences, and some transformation $f\left(\right.$ ) of the $\mathrm{X}_{t}$ variables: $h(t)=h_{0}(t) f\left(\mathrm{X}_{t} \beta\right)$. The baseline hazard $h_{0}(t)$ can either be left unspecified, giving the Cox (1972) semiparametric model, or take a specific parametric form. The different parameterizations (such as the Weibull, exponential, or Gompertz models) correspond to different assumptions about how the hazard varies with time. Choosing among them is not innocuous. In our setting, arguably none of the parametric models are suitable, for they all assume the hazard changes monotonically with time (be it increasing or decreasing). Clearly we do not expect the hazard to increase forever after announcement, but it probably does not decrease immediately either. If it did, companies would effectively never be more likely to go public than the instant they made the initial announcement. More likely, the hazard is hump-shaped: it first increases (as companies begin to clear the various legal and regulatory hurdles on their way to an IPO) and then decreases (if they have not gone public by, say, year 5, it becomes less and less likely that they ever will).

The Cox semiparametric model can easily accommodate such a hump-shaped hazard pattern (or indeed any other). It is written as $h_{i}(t)=h_{0}(t) \exp \left(x_{i t} \beta\right)$. The coefficients $\beta$, which measure the effect of our explanatory variables on the likelihood that a firm will decide to go public, are estimated via partial maximum likelihood. Note that while the Cox model avoids specification biases in $\beta$ induced by assuming an incorrect baseline hazard, it does so at the cost of a loss in efficiency: if we knew 
$h_{0}(t)$, we could estimate $\beta$ more precisely. ${ }^{19}$

\subsubsection{The IPO timing decision}

By virtue of announcing their intention to go public, all 330 sample firms are viewed as being interested in going public during our sample period. Of course, not all of them eventually do. By the end of our sampling period, December 1999, 207 companies had completed an IPO. What about the remaining 123 firms? These firms might conceivably still wish to go public in the future, after we stop following them. They are thus 'right-censored' - we potentially do not observe them for long enough to observe their final choices. Hazard models can easily correct for right-censoring (see Kalbfleisch and Prentice (1980)). ${ }^{20,21}$

Table 2 showed that eight firms from the residual group disappeared through bankruptcy and these firms presumably will not go public in future. We exclude them from the estimation sample; treating them as right-censored instead leads to lower standard errors, so our reported results are conservative.

We model the IPO timing decision as a function of

- firm-level value drivers (the company's time-varying growth in sales and earnings, in excess of the corresponding industry growth rates, and its industry-adjusted return on sales), controlling for the firm's intention to sell at least part of the existing shareholders' equity (to capture the greater difficulty of valuing control rights)

- investment opportunities (the time-varying market-to-book ratio of the median listed company in the sample firm's industry)

\footnotetext{
${ }^{19}$ In practice, our results are not sensitive to the shape of the baseline hazard. As a robustness check, we have reestimated all our models using the Weibull distribution. The coefficient estimates are very similar and frequently more significant.

${ }^{20}$ In the absence of censoring, the likelihood of the data is simply the product of the conditional densities $f\left(t_{\mathrm{i}} \mid \beta, \mathrm{x}_{\mathrm{i}}\right)$ for all observations $i$. For a censored observation, the time at which 'exit' occurs is unknown, as exit occurs after the end of the observation period, $T$. All that is known is that exit has not yet occurred as of time $T$. The appropriate contribution to the likelihood function of a censored observation is therefore the probability of not having exited prior to $T$.

${ }^{21}$ Another practical complication arises due to occasional gaps in accounting data post-announcement. Such gaps cause a firm to disappear from observation for a while. Hazard models can easily account for the resulting 'interval truncation'.
} 
- the stock market performance of the issuer's industry

- uncertainty about the firm's future profitability (using the company's age at the time of the initial announcement and the volatility of daily stock returns in the firm's DAFOX industry)

- a proxy for private benefits of control (that is, a dummy variable identifying family firms)

- macroeconomic conditions

- the cost of debt capital (the time-varying yield premium of corporate bonds over FIBOR)

- conditions in the IPO market (the trailing average of IPO initial returns over the previous four quarters and the time-varying logged number of IPOs)

- $\quad$ and industry fixed effects.

The covariates are mostly time-varying, in the sense that they take different values as time progresses. Time-varying variables are observed quarterly except for the accounting variables and market-to-book ratios, which are observed annually. Firm age is fixed at its value measured at announcement though letting it vary over time yields similar results. ${ }^{22}$

Before we present the coefficient estimates, we investigate our conjecture that the hazard is hump-shaped. Figure 3 plots the estimated hazard function from the Cox model, evaluated at the mean of the explanatory variables, with time (in years) since announcement on the horizontal axis and the probability of going public in the next quarter $\Delta t$ on the vertical axis. The hazard indeed looks hump-shaped. It peaks (at around 35\%) during the first year following the announcement and then declines.

Table 7, column 1 presents the maximum-likelihood estimates on which Figure 3 is based. Robust standard errors, reported in italics underneath the coefficient estimates, are adjusted for heteroskedasticity by clustering on firm name (that is, the various quarterly observations between announcement and final exit for a given firm are not assumed to be independent). The Wald $\chi^{2}$ test indicates that the model has good fit $(p<0.001)$. The sample size drops from 330 to 303 firms due to

\footnotetext{
${ }^{22}$ Our results are invariant to including a set of announcement-year effects to control for omitted time-specific factors.
} 
missing data on company age and family ownership and because we excluded the eight residual firms that went bankrupt.

The signs of the estimated coefficients are consistent with the prediction that increases in the hedonic value-drivers make an IPO in the next quarter $\Delta t$ more likely. Among the firm-level value drivers we find that companies are more likely to go public, the faster they increase their sales $(p=0.02)$ and earnings $(p=0.035)$ relative to the median firm in their industry, and the higher their industry-adjusted return on sales $(p=0.011)$. All three value drivers have about the same impact economically, ranging from a $13.6 \%$ to a $13.8 \%$ increase in the hazard of going public for a onestandard deviation increase in the relevant covariate. ${ }^{23}$

The estimated effect of an intention to sell secondary stock is negative and significant $(p=0.036)$. This is consistent with the interpretation that sales of control rights as embodied in existing stock pose a tougher valuation problem than sales of cash flow rights (Zingales (1995)), which thus increases the time to IPO. To gain an understanding of the economic magnitude of this effect, we convert the coefficient of -0.324 into a hazard ratio of $0.724\left(=e^{-0.324}\right)$, shown in brackets underneath the coefficient estimate. This indicates that firms intending to sell secondary stock are only $72.4 \%$ as likely to complete an IPO in the next quarter $\Delta t$ as other firms, a large effect economically. Figure $4 \mathrm{a}$ illustrates how the hazard differs between firms intending to sell secondary stock and those intending to solely raise new capital.

The median market-to-book (M/B) ratio in the sample firm's industry is included as a control for market valuations and investment opportunities. This has neither the expected positive sign nor is it significant $(p=0.651)$. We have experimented with alternative specifications for this variable, such as the market-wide $\mathrm{M} / \mathrm{B}$ ratio or the ratio of the industry and market-wide $\mathrm{M} / \mathrm{B}$ ratios, as well as lagged effects. None of these affects the hazard significantly. This contrasts with Pagano, Panetta,

\footnotetext{
${ }^{23}$ The economic magnitude of a continuous variable $\mathrm{x}_{i}$ is computed as $\exp \left(\beta_{i} \sigma_{i}\right)$ where $\beta_{i}$ is the coefficient estimate and $\sigma_{i}$ is the standard deviation of the covariate.
} 
and Zingales' (1998) findings for Italy, where industry market-to-book ratios are the single most important driver of firms' decision whether to go public. One plausible interpretation is that high $\mathrm{M} / \mathrm{B}$ ratios affect the decision to seek a stock market listing but not the subsequent timing of the IPO. Figure $2 \mathrm{a}$ is consistent with this interpretation, showing that M/B ratios increased markedly during the three years prior to the IPO announcement.

The stock market performance of the issuer's industry, on the other hand, has a positive and significant effect on the IPO hazard $(p=0.002)$. Economically, this is the second-largest effect. A one standard deviation increase in the IPO candidate's industry return over the quarter is associated with a $32.3 \%$ increase in the firm's probability of going public, all else equal. Figure 4b illustrates the magnitude of the effect for the $25^{\text {th }}$ and $75^{\text {th }}$ percentile of the distribution of industry returns. Since stock returns capture changes in market valuations, our findings lend support to Pastor and Veronesi's (2003a) prediction that firms are more likely to go public following recent improvements in market conditions, regardless of the level of valuations (i.e. M/B ratios) in the market.

The coefficient estimated for log age is positive - supporting Pastor and Veronesi's (2003a) prediction that firms prefer going public when uncertainty about their future profitability is high but it is imprecisely estimated $(p=0.127)$. This suggests that age is an imperfect proxy for valuation uncertainty in our data, though if we were to include the eight bankrupt companies in the estimation sample, the coefficient would become significant ( $p=0.048)$. Our other proxy for uncertainty fares similarly. While we find a positive relation between the IPO hazard and the volatility of stock returns in the issuer's industry, the effect is insignificant $(p=0.139)$ and remains so in alternative unreported specifications. Including only one or the other of the two proxies does not change the result. However, we do not interpret this lack of significance as contradicting Pastor and Veronesi's prediction. Due to convexity, uncertainty affects valuation especially when it is large (Pastor and Veronesi (2003b)). Our firms are both older and from more traditional sectors than is typical in the U.S., so the importance of uncertainty for IPO timing in Germany is likely more modest. 
The coefficient estimated for the family-firm dummy variable is negative and significant $(p=0.037)$ suggesting that family firms are less likely to go public, all else equal. The hazard ratio suggests that family firms are only $74 \%$ as likely to complete an IPO as other firms, a large effect economically. This is consistent with the conjectured relative importance of private benefits (though we cannot rule out that other reasons lower family firms' propensity to go public). Figure 4c illustrates how the hazard differs between family firms and non-family firms, holding all other covariates at their sample means.

Firms are more likely to complete an IPO when macroeconomic conditions, as proxied by the index of consumer confidence, are more favorable $(p=0.005)$. Economically, this variable has the largest effect on the hazard in our specification. A one-standard deviation increase in consumer confidence is associated with a $33.9 \%$ increased hazard of going public. Figure $4 d$ illustrates the magnitude of this effect for the $25^{\text {th }}$ and $75^{\text {th }}$ percentile of the distribution of consumer confidence index levels in the data. To the extent that outside valuations are higher when prospects for the economy have improved, this finding is consistent with BHS and Pastor and Veronesi (2003a), though other interpretations are certainly possible. ${ }^{24}$ In unreported tests, we have experimented with additional proxies for macroeconomic conditions, including GDP growth, forward-looking indicators of business conditions, and capacity utilization. None of these was significant.

The final three variables shown in Table 7 control for conditions in the debt and IPO markets. Neither the cost of debt capital nor the extent of underpricing in the IPO market affects the likelihood of going public significantly. An increase in IPO activity, on the other hand, has a large and negative effect $(p=0.001)$. A one standard deviation increase in the log number of IPOs reduces the hazard of completing an IPO in the next quarter $\Delta t$ by $24.7 \%$. This suggests that firms avoid going public when more IPOs compete for the attention of investors or underwriters.

In summary, our results are consistent with the key predictions of dynamic theories of IPO

\footnotetext{
${ }^{24}$ For instance, consumer confidence might proxy for retail investor sentiment, with companies timing their IPOs to coincide with periods of exuberant sentiment (Ljungqvist, Nanda, and Singh (2003)).
} 
timing. More companies go public when firm-level value drivers improve and outside valuations have increased, and consistent with BHS, firms whose controlling shareholders enjoy large private benefits of control take longer to go public.

\subsubsection{Raising outside equity}

Of the 123 firms that had not gone public by the end of our sample period, 45 raised equity from private sources. Pooling these with the 207 firms that go public, we can estimate what determines the probability that a firm raises equity from outside sources, be they public or private, in the next quarter $\Delta t$. Firms that do nothing are treated as right-censored (at the end of our sample period, they still face a non-zero probability of raising outside equity at some point in the future) unless they have gone bankrupt, in which case we exclude them from the estimation sample (as before).

The results of this model are reported in column 2 of Table 7 . The Wald $\chi^{2}$ test indicates that the model has good fit $(p<0.001)$. The coefficients resemble those in column 1 , though they are generally estimated less precisely. As before, family firms are less likely to raise outside equity $(p=0.05)$ while the hazard of raising outside equity increases in industry-adjusted sales growth $(p=0.085)$, earnings growth $(p=0.074)$, and ROS $(p=0.031)$ as well as stock market returns in the firm's industry $(p=0.006)$ and consumer confidence $(p<0.001)$. An intention to sell secondary shares is associated with a lower likelihood of raising external equity $(p=0.048)$.

\subsubsection{The choice between going public and raising equity privately}

One possible interpretation of the great degree of similarity between the findings in columns 1 and 2 is that the forces underlying dynamic theories of IPO timing apply more generally to firms' decision whether to raise outside equity, not just the decision to go public. In other words, the forces modeled by BHS and Pastor and Veronesi (2003a) may determine not so much the decision when to go public, but companies' demand for equity capital irrespective of the source. If so, these forces should be equally good at explaining when firms raise equity privately.

To test this conjecture, we now refine the firms' choice set, allowing them to choose between 
raising outside equity from public (IPO) or private sources. As before, firms that do nothing are treated as right-censored unless they have gone bankrupt. The relative determinants of these choices can be estimated using a competing-risk model. This assumes that firms are 'at risk' from each choice in the next time interval $\Delta t$. That is, they can exit from the sample either by going public or by raising equity privately. ${ }^{25}$

Competing-risk models are estimated by factoring the overall likelihood function into several choice-specific likelihood functions and estimating each individually. This assumes that the underlying hazards are independent, in the usual maximum-likelihood sense. Thus, the baseline hazards $h_{0}$ and the effects of the covariates $X_{t}$ are allowed to vary across choices. For example, an event which makes going public more attractive is not constrained to have a positive impact on the probability of raising equity privately. The model shown in column 1 of Table 7 represents the exitby-IPO part of the competing risk model. What remains to be estimated is the exit-by-private-sale part, which is reported in column $3 .^{26}$

With the exception of the index of consumer confidence $(p=0.013)$ and the cost of debt $(p=0.059)$, none of our covariates significantly affects the hazard of raising equity privately. The Wald $\chi^{2}$ test cannot reject the null hypothesis that all covariates are jointly zero $(p=0.275)$. This lack of fit suggests that dynamic theories of IPO timing that stress the importance of outside valuations cannot explain the decision to raise equity privately. By inference, such theories appear to apply specifically to the IPO decision rather than more generally to firms' decision when to raise outside equity.

\footnotetext{
${ }^{25}$ We treat exits as 'absorbing', meaning that having exited, a firm is no longer at risk from the other choice. For instance, a firm that has gone public is assumed no longer to seek equity from private sources.

${ }^{26}$ Independent competing-risk models are estimated as follows. For each exit choice, treat firms as right-censored if they did not choose the exit under consideration. Then estimate the hazard model by maximizing the resulting partial likelihood function. Repeat for each possible exit. See Lancaster (1996).
} 


\section{Conclusion}

In this paper, we attempt to test recent theories of IPO timing using a hand-collected sample of German IPO candidates which we track from announcement to IPO. Our analysis contributes to a growing literature on why and when firms go public. While the first question is theoretically well understood, the second question has only recently received attention. Two prominent examples are Benninga, Helmantel, and Sarig (2003) and Pastor and Veronesi (2003a).

In Benninga et al. (2003), a firm chooses dynamically between staying private and going public, trading off the higher valuations diversified outside investors are willing to pay for the stock of a public firm and the loss of private benefits of control that going public is assumed to entail. Improvements in a firm's cash flows and prospects increase outside investors' valuations and so affect whether and when the firm goes public. Pastor and Veronesi emphasize the importance of changes in valuations (as captured by returns) rather than valuation levels (say, a high market-tobook ratio in the industry). All else equal, they predict that firms are more likely to go public following recent improvements in market conditions, regardless of the level of valuations in the market. In addition, more firms go public when uncertainty about their future profitability is high.

We test the predictions of these models with a set of 330 privately-held German firms that between 1984 and 1995 announced their intention to go public. We follow these firms over time, observing whether, when, and how they sold equity to outside investors, and relate these decisions to proxies for outside investors' time-varying valuations of the firm's stock. Our results are consistent with the key predictions of the models. Controlling for private benefits, we find that increases over time in measures of firms' investment opportunities and valuations have a significant, and sizeable, effect on the likelihood that firms will complete an initial public offering. We also show that these effects are distinct from factors that increase firms' demand for outside capital more generally. 


\section{References}

Altinkilic, O., and R.S. Hansen, 2000, "Are There Economies of Scale in Underwriting Fees? Evidence of Rising External Financing Costs," Review of Financial Studies 13, 191-218.

Amihud, Y., and H. Mendelson, 1988, "Liquidity and Asset Prices: Financial Management Implications", Financial Management (Spring), 5-15.

Anderson, R.C., S.A. Mansi, and D.M. Reeb, 2003, "Founding Family Ownership and the Agency Cost of Debt," Journal of Financial Economics 68, 263-285.

Benninga, S., M. Helmantel, and O. Sarig, 2003, “The Timing of Initial Public Offerings,” Journal of Financial Economics, forthcoming.

Benveniste, L.M., and P.A. Spindt, 1989, "How Investment Bankers Determine the Offer Price and Allocation of New Issues," Journal of Financial Economics 24, 343-361.

Benveniste, L.M., A. Ljungqvist, W.J. Wilhelm, and X. Yu, 2003, "Evidence of Information Spillovers in the Production of Investment Banking Services," Journal of Finance 58, 577-608.

Black, B.S., and R.J. Gilson, 1998, "Venture Capital and the Structure of Capital Markets: Banks Versus Stock Markets," Journal of Financial Economics 47, 243-277.

Bolton, P., and E.-L. von Thadden, 1998, “Blocks, Liquidity and Corporate Control," Journal of Finance 53, 1-26.

Boot, A.W.A., R. Gopalan, and A.V. Thakor, 2003, "Go Public or Stay Private: A Theory of Entrepreneurial Choice", unpublished working paper, Washington University in St. Louis.

Brau, J.C., B. Francis, and N. Kohers, 2003, “The Choice of IPO Versus Takeover,” Journal of Business 76, 583-612.

Burkart, M., F. Panunzi, and A. Shleifer, 2003, "Family Firms," Journal of Finance, forthcoming.

Busaba, W., L.M. Benveniste, and R.-J. Guo, 2001, "The Withdrawal of Initial Public Offerings during the Premarket," Journal of Financial Economics 60, 73-102.

Chemmanur, T.J., and P. Fulghieri, 1999, “A Theory of the Going-public Decision,” Review of Financial Studies 12, 249-280.

Choe, H., R.W. Masulis, and V. Nanda, 1993, "Common Stock Offerings Across the Business Cycle: Theory and Evidence," Journal of Empirical Finance 1, 3-32.

Cook, D.O., and R. Kieschnick, 2003, "Evidence on the Timing of Going Public and Going Private Transactions," unpublished working paper, University of Texas at Dallas.

Cox, D.R., 1972, "Regression Models and Life-tables," Journal of the Royal Statistical Society 34, $187-220$.

Dow, J., and G. Gorton, 1997, "Stock Market Efficiency and Economic Efficiency: Is There a Connection?" Journal of Finance 52, 1087-1129.

Dyck, A., and L. Zingales, 2002, "Private Benefits of Control," Journal of Finance, forthcoming.

Franks, J., and C. Mayer, 2001, "Ownership and Control of German Corporations," Review of Financial Studies 14, 943-77. 
Hellmann, T. and M. Puri, 2000, "The Interaction Between Product Market and Financing Strategy: The Role of Venture Capital," Review of Financial Studies 13, 959-984.

Helwege, J., and N. Liang, 2004, "Initial Public Offerings in Hot and Cold Markets", Journal of Financial and Quantitative Analysis, forthcoming.

Helwege, J., and F. Packer, 2003, “The Decision to Go Public: Evidence from Mandatory SEC Filings by Private Firms," unpublished working paper, Ohio State University.

Holmström, B., and J. Tirole, 1993, "Market Liquidity and Performance Monitoring," Journal of Political Economy 101, 678-709.

Kalbfleisch, J.D., and R.L. Prentice, 1980, The Statistical Analysis of Failure Time Data, John Wiley \& Sons, New York.

La Porta, R., F. Lopes-de-Silanes, and A. Shleifer, 1999, "Corporate Ownership Around the World," Journal of Finance 54, 471-517.

Lancaster, T., 1996, The Econometric Analysis of Transition Data, Cambridge University Press, Cambridge.

Leland, H., and D. Pyle, 1977, "Informational Asymmetries, Financial Structure, and Financial Intermediation," Journal of Finance 32, 371-387.

Lerner, J., 1994, "Venture Capitalists and the Decision to Go Public," Journal of Financial Economics 35, 293-316.

Ljungqvist, A., T.J. Jenkinson, and W.J. Wilhelm, 2003, "Global Integration of Primary Equity Markets: The Role of U.S. Banks and U.S. Investors," Review of Financial Studies 16, 63-99.

Ljungqvist, A., V. Nanda, and R. Singh, 2003, "Hot Markets, Investor Sentiment, and IPO Pricing”, unpublished working paper, New York University.

Lowry, M., 2003, “Why Does IPO Volume Fluctuate So Much?” Journal of Financial Economics $67,3-40$.

Lowry, M., and G.W. Schwert, 2002, "IPO Market Cycles: Bubbles or Sequential Learning?" Journal of Finance 57, 1171-1200.

Maug, E., 2001, "Ownership Structure and the Life-Cycle of the Firm: A Theory of the Decision to Go Public," European Finance Review 5, 167-200.

Mello, A.S., and J.E. Parsons, 1998, "Going Public and the Ownership Structure of the Firm," Journal of Financial Economics 49, 79-109.

Mikkelson, W., M.M. Partch, and K. Shah, 1997, "Ownership and Operating Performance of Companies that Go Public,” Journal of Financial Economics 44, 281-307.

Nenova, T., 2003, "The Value of Corporate Voting Rights and Control: A Cross-Country Analysis," Journal of Financial Economics 68, 325-51.

Ongena, S., and D.C. Smith, 2001, “The Duration of Bank Relationships,” Journal of Financial Economics 61, 449-475.

Pagano, M., and A. Röell, 1998, “The Choice of Ownership Structure: Agency Costs, Monitoring and the Decision to Go Public," Quarterly Journal of Economics 113, 187-225.

Pagano, M., F. Panetta, and L. Zingales, 1998, "Why Do Companies Go Public? An Empirical Analysis," Journal of Finance 53, 27-64. 
Pastor, L., and P. Veronesi, 2003a, "IPO Waves and Stock Prices,” unpublished working paper, University of Chicago.

Pastor, L., and P. Veronesi, 2003b, "Stock Valuation and Learning about Profitability," Journal of Finance 58, 1749-1789

Ritter, J.R., 1984, “The Hot Issue Market of 1980,” Journal of Business 57, 215-240.

Röell, A., 1996, “The Decision to Go Public: An Overview,” European Economic Review 40, 10711081.

Stoughton, N.M., and J. Zechner, 1998, "IPO Mechanisms, Monitoring, and Ownership Structure," Journal of Financial Economics 49, 45-77.

Subrahmanyam, A., and S. Titman, 1999, "The Going Public Decision and the Development of Financial Markets," Journal of Finance 54, 1045-1082.

Volpin, P., 2000, “Ownership Structure, Banks, and Private Benefits of Control,” unpublished working paper, London Business School.

Welch, I., 1989, "Seasoned Offerings, Imitation Costs, and the Underpricing of Initial Public Offerings," Journal of Finance 44, 421-449.

Zingales, L., 1995, "Insider Ownership and the Decision to Go Public," Review of Economic Studies $62,425-448$. 
Figure 1. Sample distribution of announcements

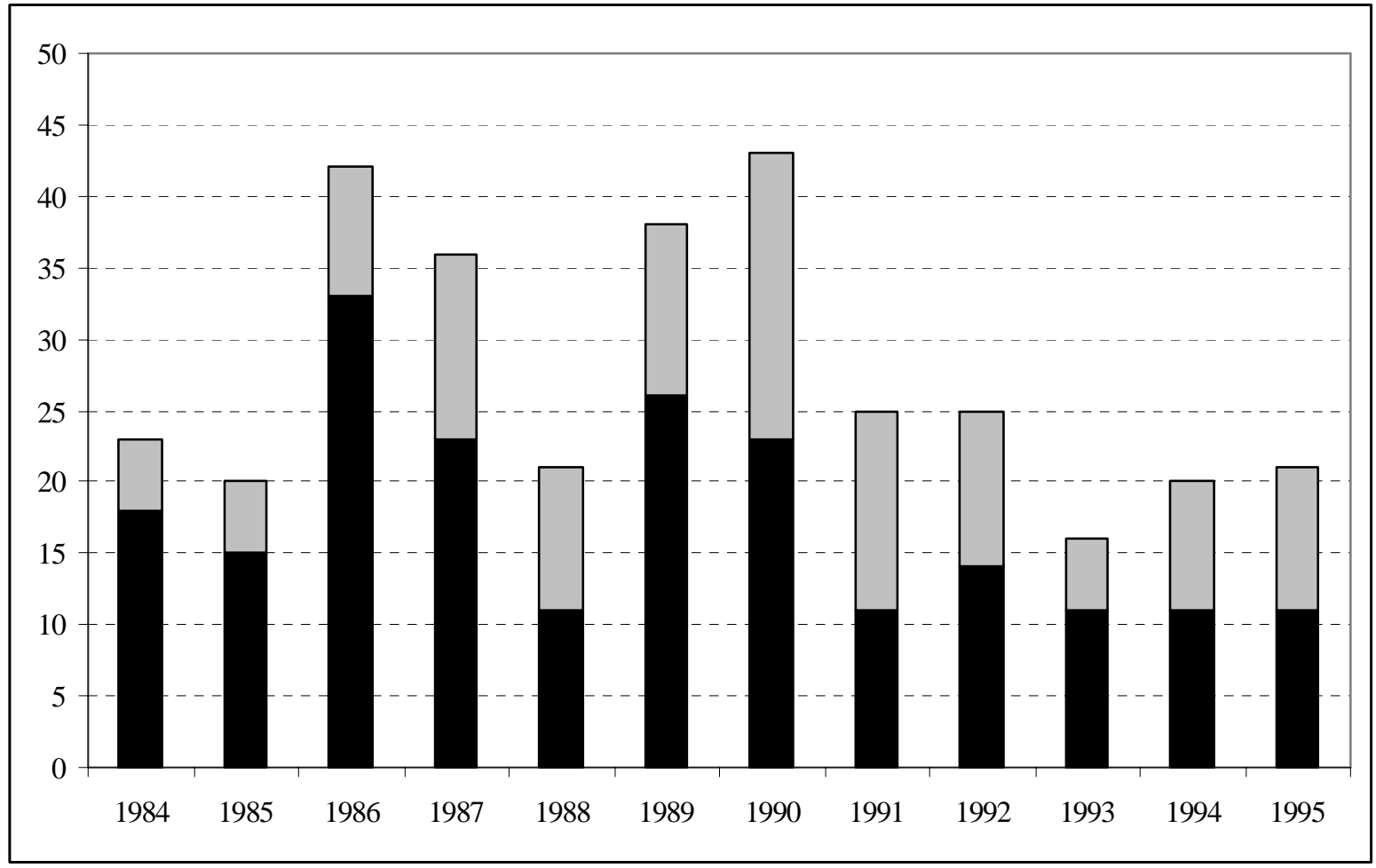

The sample consists of 330 firms that announced their intention to go public in Germany between 1984 and 1995. The figure shows the annual number of IPO announcements and (in black) the number of announcements that eventually led to an IPO by December 1999, the end of our sampling period. 
Figure 2a. Median industry market/book ratio

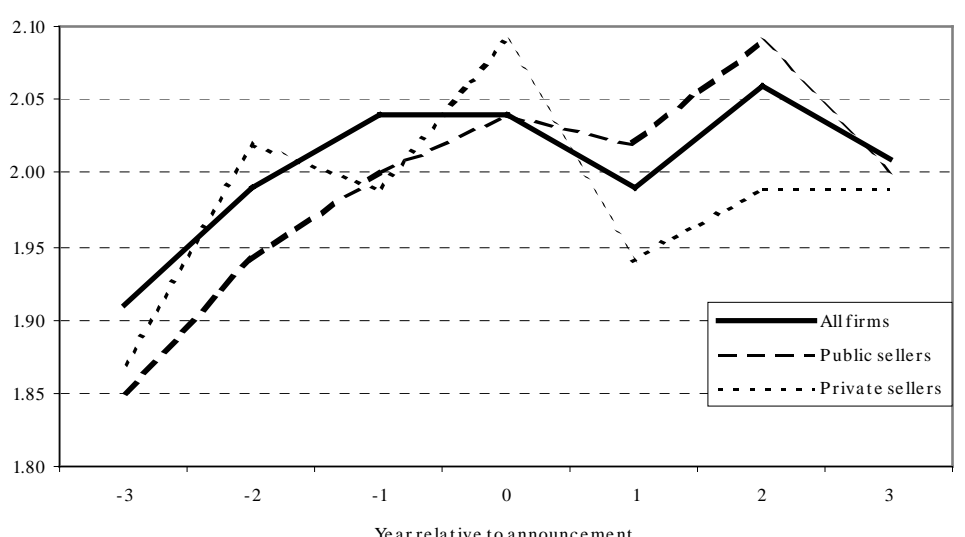

Figure 2b. Median industry stock return (\%)

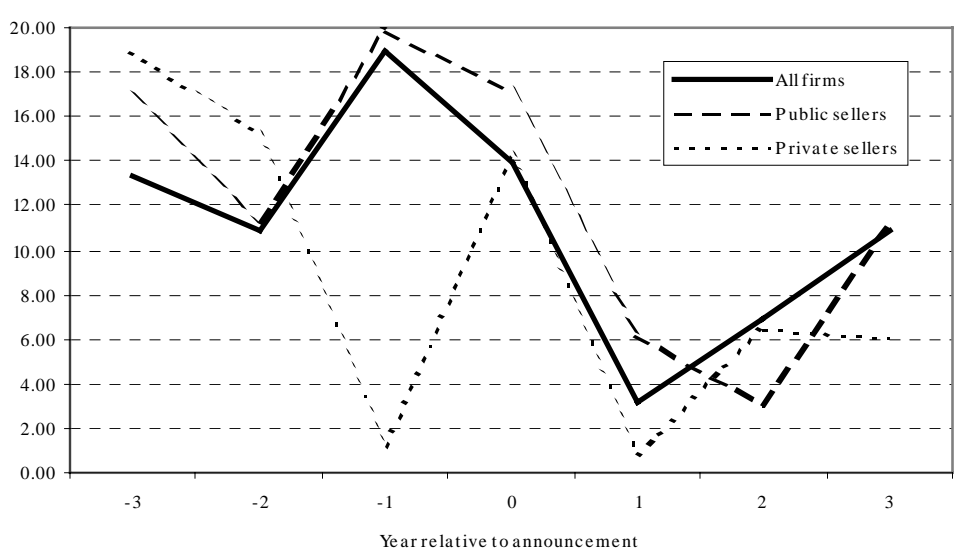

Figure 2c. Median daily industry volatility (\%)

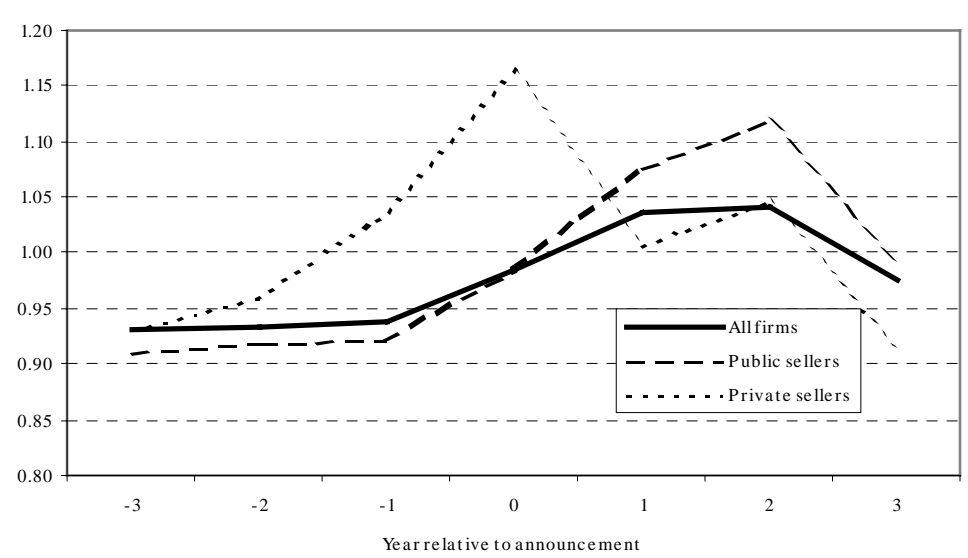

Figure 2d. Median consumer confidence index

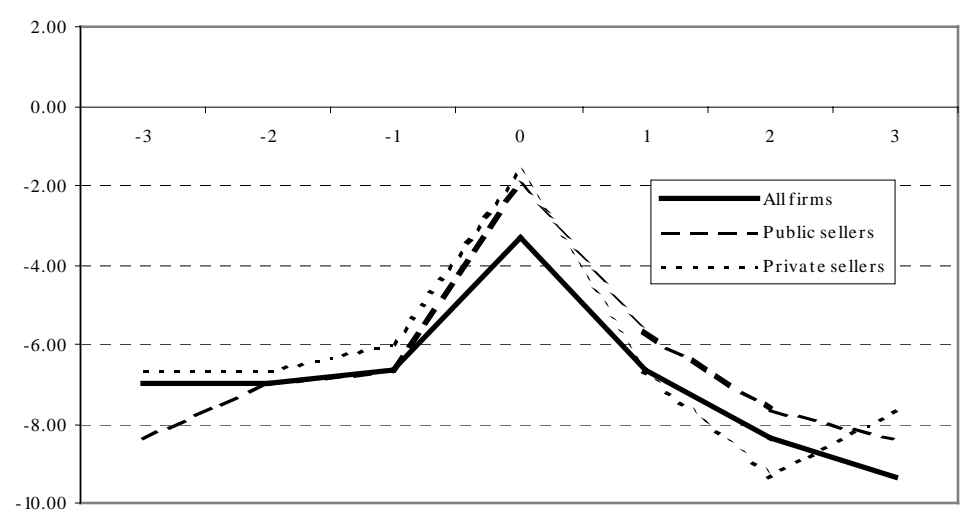

Year relat tive to announcement 
Figure 2e. Median corporate bond yield - FIBOR (\%)

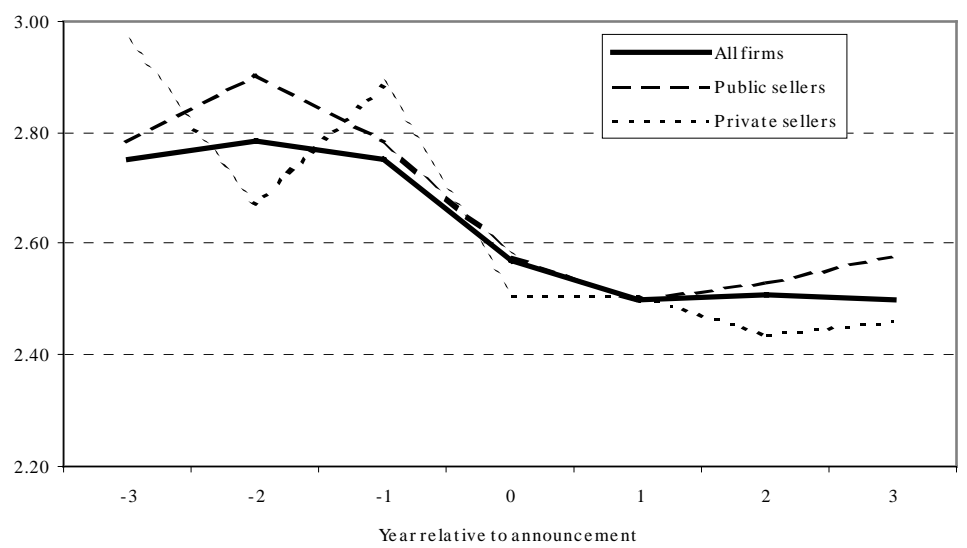

Figure 2f. Median IPO underpricing (\%)

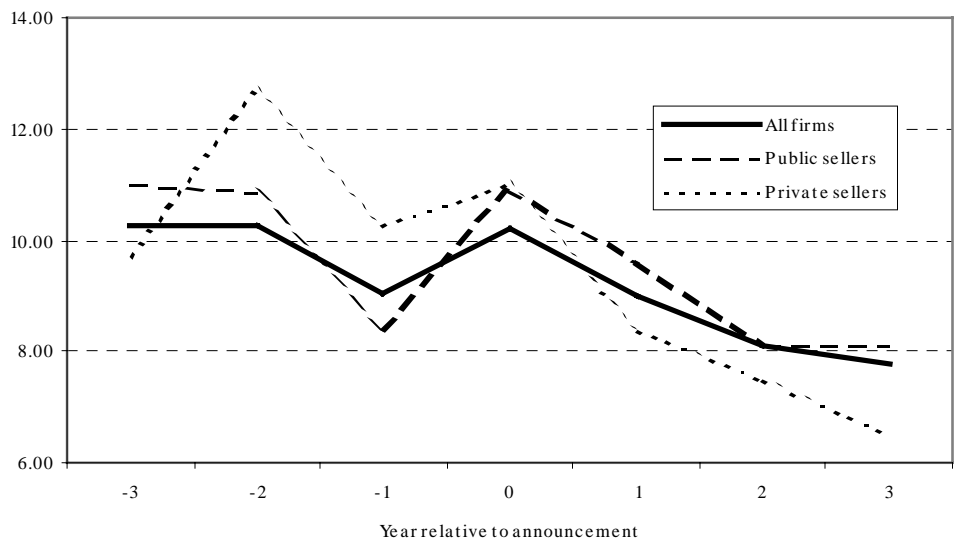

Figure 2g. Median number of completed IPOs

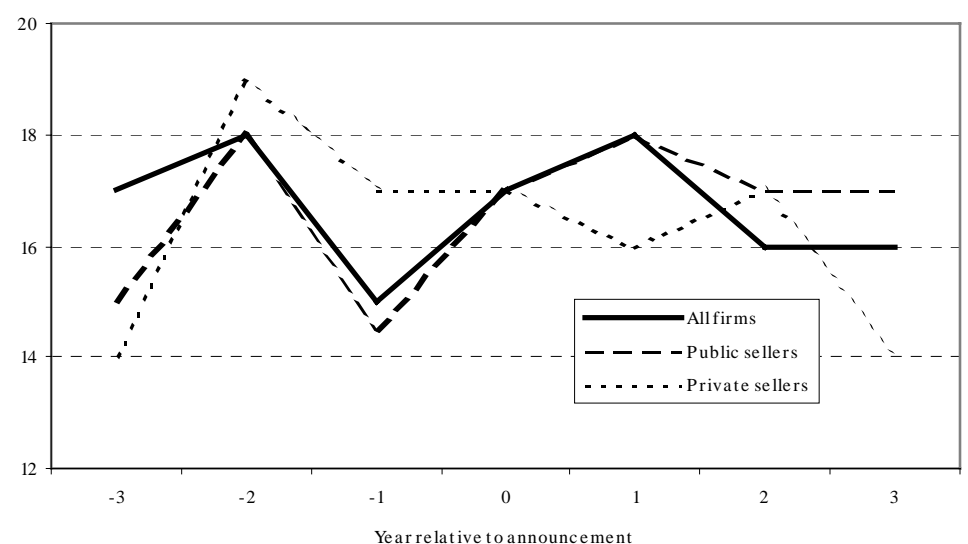

Figures $2 \mathrm{a}$ through $2 \mathrm{~g}$ show the evolution of seven indicators of external conditions, from three years before the IPO announcement to three years after. Each figure shows three graphs: the solid line refers to the median sample firm, while the dashed and dotted lines identify the median public and private seller, respectively. In 2a, we use annual market-to-book ratios at the industry level to proxy for investment opportunities. Specifically, for every listed company that is covered in Worldscope, we compute a market-to-book ratio as of the end of each calendar year. We then assign the detailed Worldscope industries to the 12 DAFOX industries that our sample companies are grouped under. We take as our proxy for investment opportunities in industry $j$ in year $t$ the median listed company's market-to-book ratio in that industry at the end of year $t$. In $2 \mathrm{~b}$, we show annual value-weighted index returns in the IPO candidate's DAFOX industry. Volatility in $2 \mathrm{c}$ is measured as the standard deviation of daily index returns in the IPO candidate's DAFOX industry. In $2 \mathrm{~d}$, we use the index of German consumer confidence compiled by GfK on behalf of the European Commission. A positive reading means most consumers are expecting an improvement over the next 12 months, while a negative reading means most consumers are expecting a deterioration. The corporate bond yield in $2 \mathrm{e}$ is taken from the Bundesbank's monthly publications, while FIBOR (the Frankfurt Inter-Bank Offered Rate) comes from Datastream. Underpricing returns in $2 \mathrm{f}$ are calculated as the average percentage change from the offer price to the first-day trading price for all firms completing an IPO in the relevant calendar year. 
Figure 3. Estimated hazard function

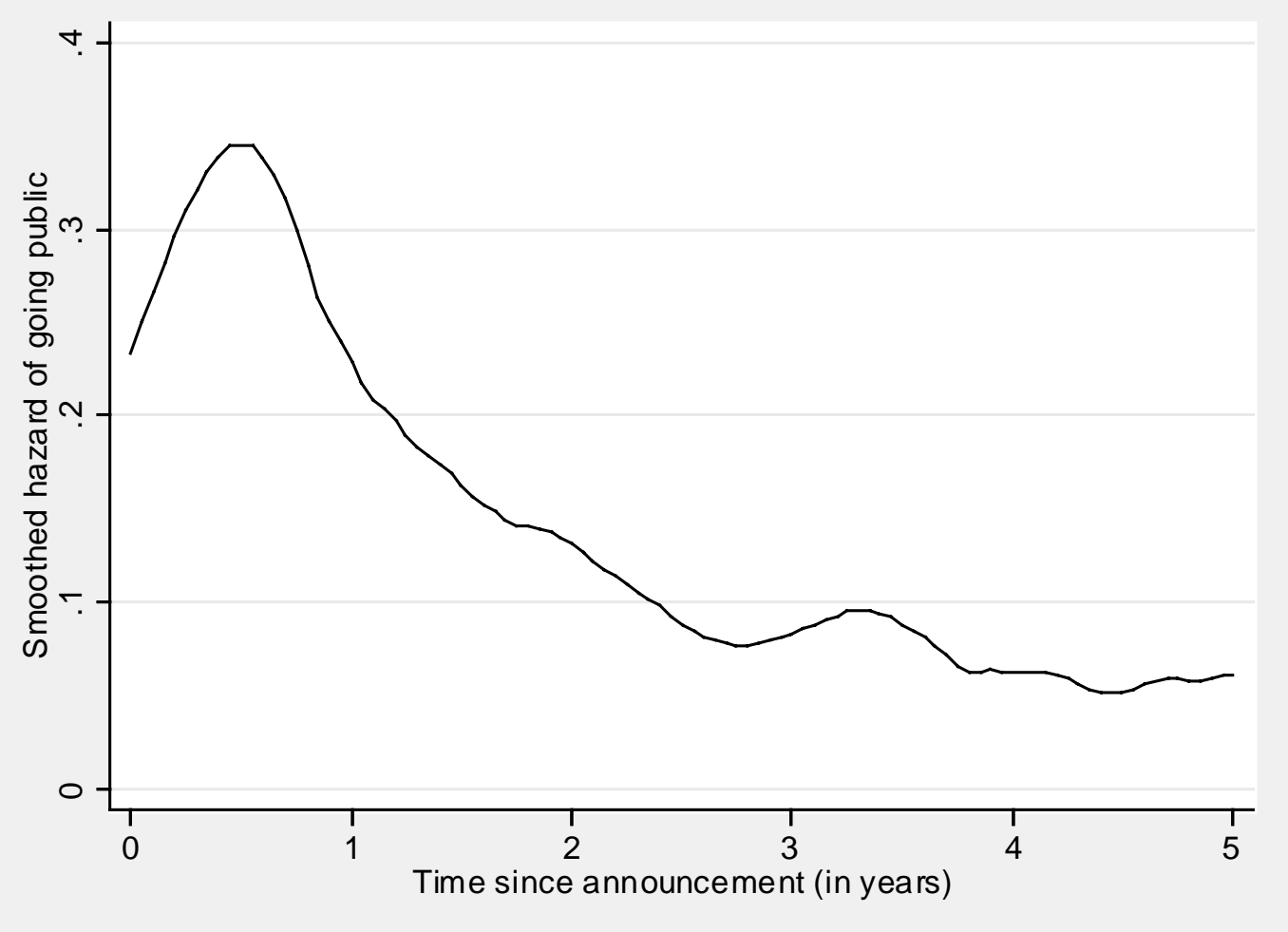

The figure shows the hazard function estimated from the Cox model shown in Table 7, column 1, for the first five years since announcement. The hazard is evaluated at the mean values of the explanatory variables. 
Figure 4a. Firms intending secondary sales vs. others

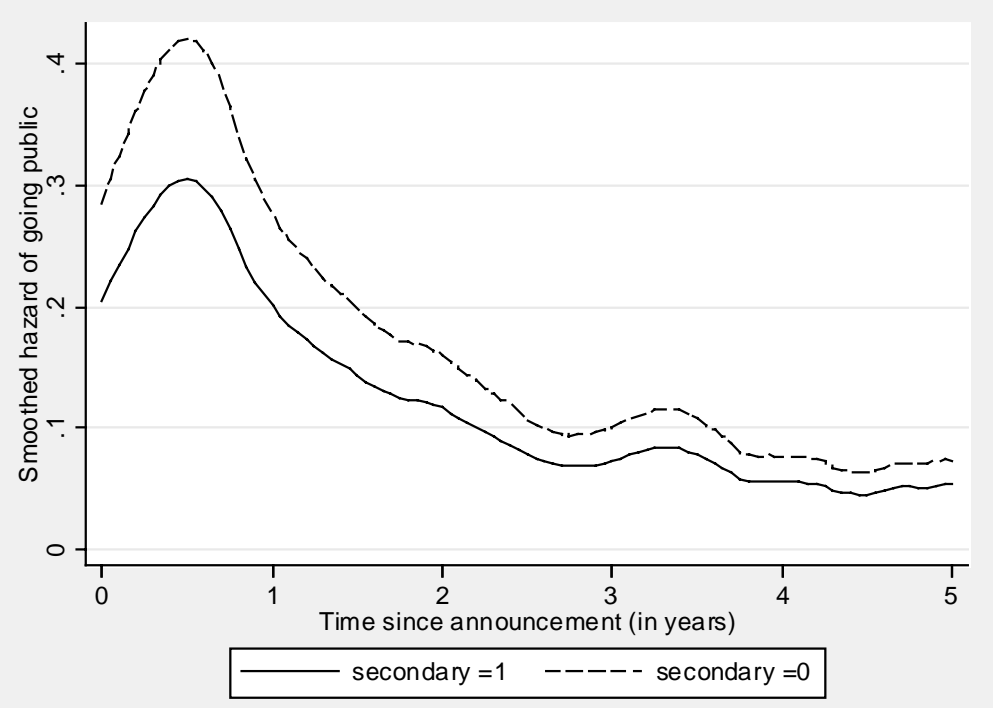

Figure 4b. Effect of industry returns

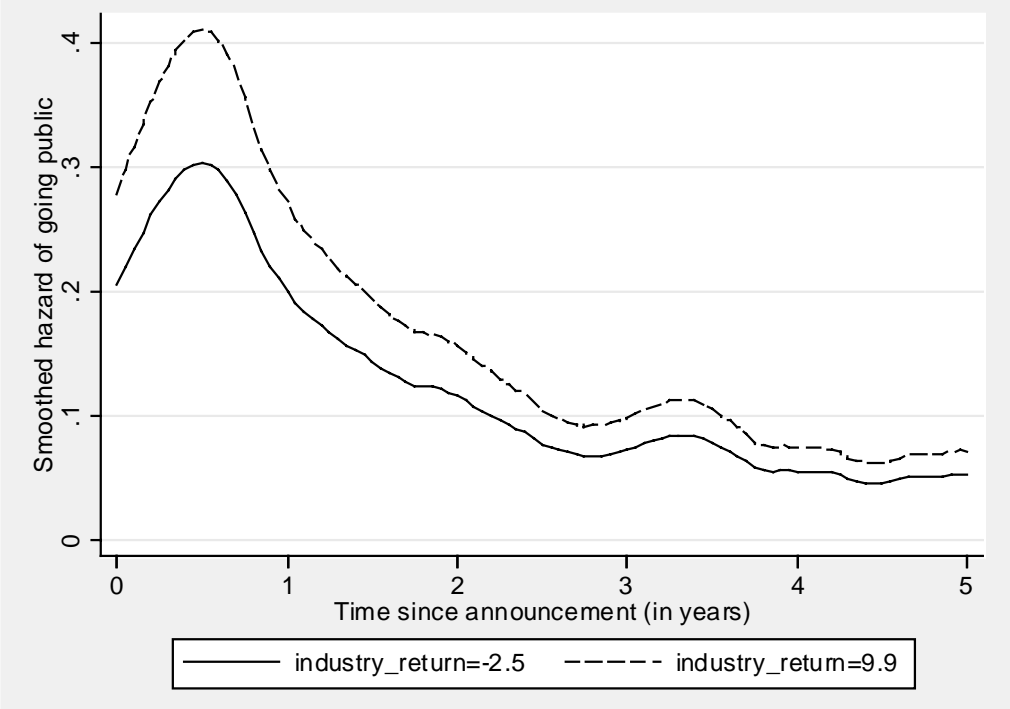

Figure 4c. Family firms vs. others

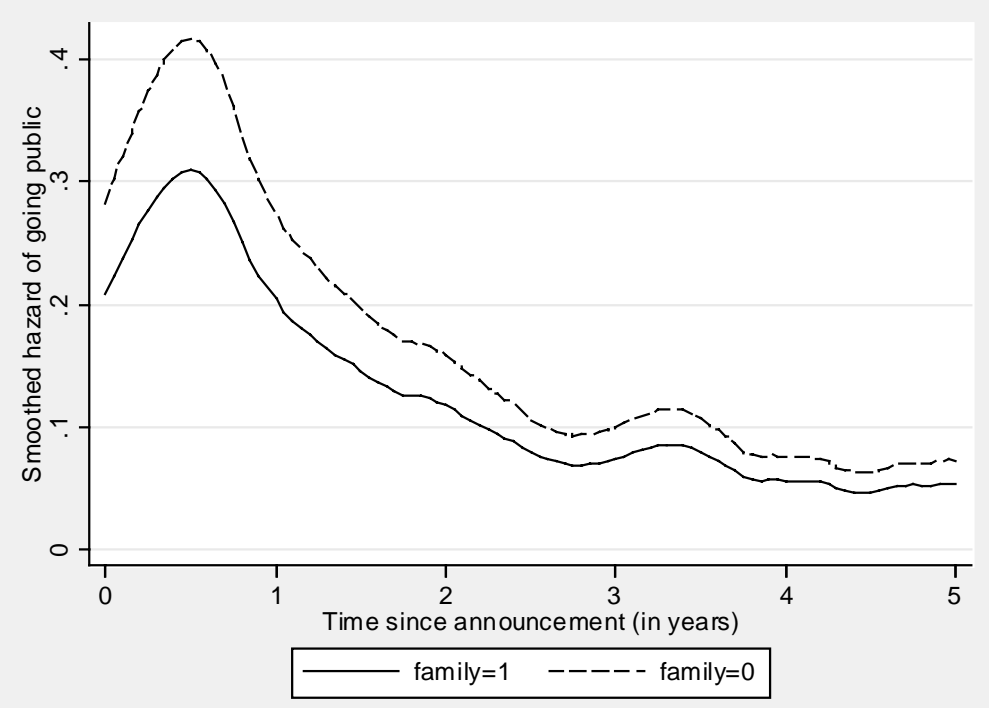

Figure 4d. Effect of consumer confidence

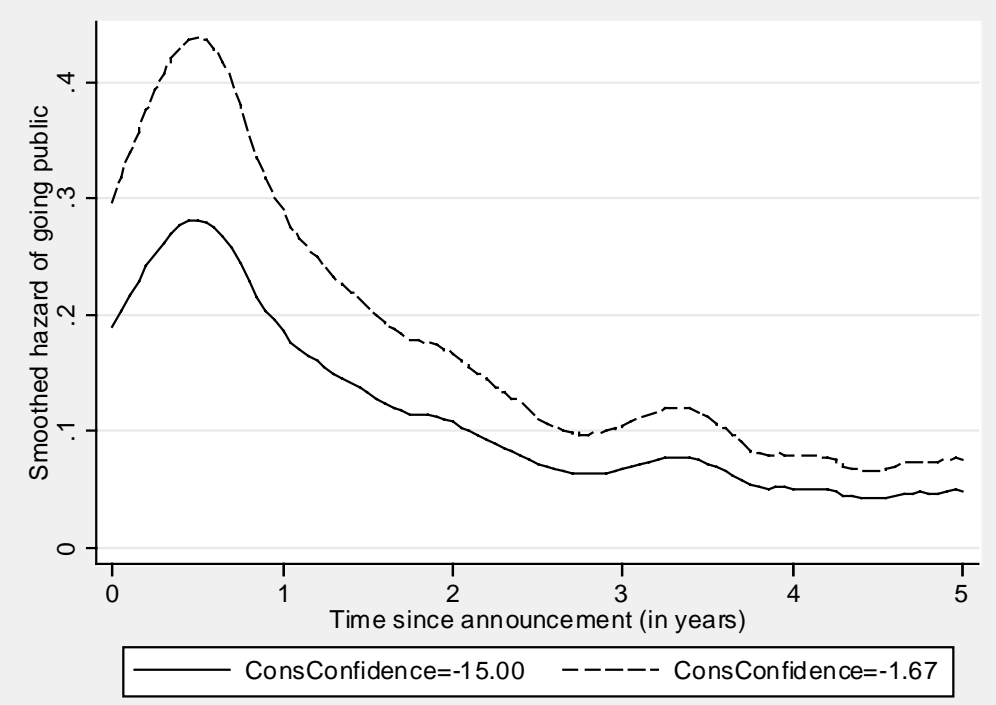


Figures 4a through 4d illustrate the economic magnitude of the effect of four covariates on the hazard of going public, based on the hazard function estimated from the Cox model shown in Table 7, column 1. The hazard is evaluated at representative values of the covariate in question and the mean values of all other explanatory variables. Specifically, in Figure 4a, the hazard is evaluated for firms intending to sell secondary shares and those intending to raise only new capital. All else equal, firms intending to sell secondary stock have a lower hazard of going public. In Figure $4 \mathrm{~b}$, it is evaluated at the $25^{\text {th }}$ and $75^{\text {th }}$ percentile of the distribution of industry stock returns. In Figure $4 c$, it is evaluated for family firms and non-family firms. In Figure $4 d$, it is evaluated at the $25^{\text {th }}$ and $75^{\text {th }}$ percentile of the distribution of consumer confidence index levels in the data. 
Table 1. Industry breakdown

\begin{tabular}{clrr}
\hline $\begin{array}{c}\text { DAFOX } \\
\text { code }\end{array}$ & Description & \multicolumn{2}{c}{ Frequency } \\
\hline & & Number & $(\%)$ \\
803 & Chemicals, plastics, pharmaceuticals & 16 & 4.8 \\
804 & Electrical engineering, electronics & 47 & 14.2 \\
805 & Utilities, energy, coal, oil, gas & 14 & 4.2 \\
806 & Banks, insurance & 21 & 6.4 \\
807 & Mechanical engineering, machine tools, car manufacturers, car parts & 59 & 17.9 \\
808 & Steel, metal, wires, cable & 12 & 3.6 \\
809 & Construction, building materials & 34 & 10.3 \\
810 & Retail trade, department stores & 21 & 6.4 \\
811 & Consumer goods, food, breweries, paper, entertainment & 96 & 29.1 \\
812 & Transportation & 5 & 1.5 \\
813 & Holding companies & 0 & 0.0 \\
814 & Miscellaneous & 5 & 1.5 \\
& & & \\
Total & & 330 & 100.0 \\
& & & \\
\hline
\end{tabular}

The sample consists of 330 firms that announced their intention to go public in Germany between 1984 and 1995. In the absence of SIC codes for private companies, we use news stories, company reports, and information from Worldscope to assign the sample companies to the 12 industries covered by the DAFOX family of stock market indices. These cover all officially listed German companies, accounting for more than $90 \%$ of market capitalization. They are thus considerably broader than the better-known DAX index of the 30 leading shares. Unlike the DAX, the DAFOX indices are computed according to consistent rules that ensure comparability over time. 
Table 2. Reported IPO withdrawal reasons

\begin{tabular}{|c|c|c|c|c|c|c|}
\hline \multirow{2}{*}{ Reason (not mutually exclusive) } & \multicolumn{2}{|c|}{$\begin{array}{l}\text { All non-IPO firms } \\
\text { (123 firms) }\end{array}$} & \multicolumn{2}{|c|}{$\begin{array}{c}\text { Private sellers } \\
\text { (45 firms) }\end{array}$} & \multicolumn{2}{|c|}{$\begin{array}{c}\text { Residual group } \\
\text { (78 firms) }\end{array}$} \\
\hline & & & & & & \\
\hline Poor company performance & 39 & $32 \%$ & 22 & $49 \%$ & 17 & $22 \%$ \\
\hline ... of which: financial distress & 13 & $11 \%$ & 5 & $11 \%$ & 8 & $10 \%$ \\
\hline Poor industry performance & 9 & $7 \%$ & 3 & $7 \%$ & 6 & $8 \%$ \\
\hline Poor stock market conditions & 3 & $2 \%$ & 2 & $4 \%$ & 1 & $1 \%$ \\
\hline Internal disputes & 3 & $2 \%$ & 0 & $0 \%$ & 3 & $4 \%$ \\
\hline Did not meet lead bank requirements & 1 & $1 \%$ & 1 & $2 \%$ & 0 & $0 \%$ \\
\hline High cost of flotation & 1 & $1 \%$ & 1 & $2 \%$ & 0 & $0 \%$ \\
\hline
\end{tabular}

The table uses company announcements and press reports to show why the 123 firms that did not go public withdrew their IPO plans. The table only reports answers for the firms that explicitly reported a reason for not raising equity publicly. 
Table 3. Firm-specific value drivers

\begin{tabular}{|c|c|c|c|c|c|}
\hline & Year & $\begin{array}{c}\text { Whole } \\
\text { sample } \\
\text { (330 firms) }\end{array}$ & $\begin{array}{c}\text { Public } \\
\text { sellers } \\
\text { (207 firms) } \\
\end{array}$ & $\begin{array}{c}\text { Private } \\
\text { sellers } \\
\text { (45 firms) } \\
\end{array}$ & $\begin{array}{c}\text { Residual } \\
\text { group } \\
\text { (78 firms) }\end{array}$ \\
\hline \multicolumn{6}{|l|}{ Sales and earnings levels } \\
\hline \multirow{4}{*}{ Sales (DEM m) } & -3 & 217.3 & 197.9 & 253.9 & 286.4 \\
\hline & -2 & 198.4 & 197.6 & 171.0 & 226.2 \\
\hline & -1 & 208.6 & 206.3 & 191.5 & 235.8 \\
\hline & 0 & 224.9 & 204.6 & 188.3 & 288.0 \\
\hline \multirow[t]{4}{*}{ Earnings (DEM m) } & -3 & 4.9 & 4.8 & 2.7 & 12.6 \\
\hline & -2 & 5.0 & 5.4 & 2.8 & 3.4 \\
\hline & -1 & 6.9 & 7.1 & 5.0 & 8.6 \\
\hline & 0 & 7.3 & 7.8 & 4.2 & 7.2 \\
\hline \multicolumn{6}{|l|}{ Performance } \\
\hline \multirow[t]{3}{*}{ Industry-adjusted sales growth (\%) } & {$[-3 ;-2]$} & $22.7^{* * *}$ & $21.7^{* * *}$ & $16.2^{* * *}$ & $27.6^{* * * *}$ \\
\hline & {$[-2 ;-1]$} & $18.9^{* * *}$ & $19.3^{* * * *}$ & $16.5^{* * *}$ & $15.2^{* * *}$ \\
\hline & {$[-1 ; 0]$} & $16.3^{* * *}$ & $17.5^{* * *}$ & $23.4^{* * *}$ & $9.4^{* * *}$ \\
\hline \multirow[t]{3}{*}{ Industry-adjusted earnings growth (\%) } & {$[-3 ;-2]$} & $17.9^{* * *}$ & $25.0^{* * *}$ & 11.1 & -8.1 \\
\hline & {$[-2 ;-1]$} & $29.4^{* * *}$ & $35.4^{* * *}$ & 19.1 & -26.4 \\
\hline & {$[-1 ; 0]$} & $10.1^{* * *}$ & $14.9^{* * *}$ & -6.8 & -28.8 \\
\hline \multicolumn{6}{|l|}{ Profitability } \\
\hline \multirow[t]{4}{*}{ Industry-adjusted return on sales (\%) } & -3 & $0.4^{* *}$ & $0.3^{* *}$ & -0.3 & 0.6 \\
\hline & -2 & $0.8^{* * * *}$ & $0.8^{* * *}$ & -0.4 & 1.0 \\
\hline & -1 & $1.1^{* * * *}$ & $1.1^{* * * *}$ & 0.8 & $2.0^{* * *}$ \\
\hline & 0 & $1.4^{* * *}$ & $1.7^{* * *}$ & -0.1 & $0.8^{* * *}$ \\
\hline Age & 0 & 38 & 48 & 28 & 25 \\
\hline
\end{tabular}

The sample consists of 330 firms that announced their intention to go public in Germany between 1984 and 1995 . Public sellers are firms that by December 1999 had gone on to raise public equity by floating on a stock exchange. Private sellers are firms that raised equity from private sources instead. The residual group contains firms that either had gone bankrupt or are right-censored in the sense that we do not track them for long enough to observe their final choices. The table reports certain firm characteristics that may be interpreted as value drivers: sales and earnings levels and growth rates as measures of performance, and return on sales (ROS) as a measure of profitability. Sales and earnings levels are deflated to 1991 purchasing power using the GDP deflator. Growth in sales and earnings is adjusted for industry trends by subtracting the corresponding growth rate for the median German firm in the same industry as the IPO candidate. ROS is similarly adjusted by subtracting the corresponding ROS for the median German firm in the same industry. The data underlying the industry adjustments come from Worldscope. For each of these variables, we report the median for the three years prior to the IPO announcement as well as the fiscal year in which the announcement took place (year 0). For all industry-adjusted variables, we test whether the median equals zero using a Wilcoxon signed-rank test. We use ${ }^{* * * * * *},{ }^{*}$, and ${ }^{*}$ to indicate significance at the $1 \%, 5 \%$, and $10 \%$ level, respectively. Finally, we report company age at announcement as a proxy for uncertainty about future profitability. All else equal, younger companies pose a greater valuation problem due to their relative lack of track record. 
Table 4. Why do firms intend to go public?

\begin{tabular}{|c|c|c|c|c|c|c|c|c|}
\hline \multirow{2}{*}{$\begin{array}{l}\text { Stated reason } \\
\text { Issue primary shares only }\end{array}$} & \multicolumn{2}{|c|}{$\begin{array}{c}\text { Whole sample } \\
\text { (330 firms) }\end{array}$} & \multicolumn{2}{|c|}{$\begin{array}{l}\text { Public sellers } \\
\text { (207 firms) }\end{array}$} & \multicolumn{2}{|c|}{$\begin{array}{c}\text { Private sellers } \\
\text { (45 firms) }\end{array}$} & \multicolumn{2}{|c|}{$\begin{array}{c}\text { Residual group } \\
\text { (78 firms) }\end{array}$} \\
\hline & 132 & $40.0 \%$ & 88 & $42.5 \%$ & 22 & $48.9 \%$ & 22 & $28.2 \%$ \\
\hline & & & 11 & & & & & \\
\hline Issue secondary shares or both & 198 & $60.0 \%$ & 9 & $57.5 \%$ & 23 & $51.1 \%$ & 56 & $71.8 \%$ \\
\hline Divestiture & 34 & $10.3 \%$ & 20 & $9.7 \%$ & 10 & $22.2 \%$ & 4 & $5.1 \%$ \\
\hline Financial institutions to sell out & 13 & $3.9 \%$ & 3 & $1.4 \%$ & 5 & $11.1 \%$ & 5 & $6.4 \%$ \\
\hline
\end{tabular}

The table outlines the reasons for seeking to go public as stated by the firms themselves at the time of their IPO announcements. We categorize listing reasons as purely primary (raising capital) and secondary (cashing out, including combinations of primary and secondary). Reasons are extracted from company announcements and news reports. Divestiture is defined as selling the whole or a significant part of the business for the benefit of the corporate owner. Financial institutions include banks and venture capitalists. 
Table 5. Ownership structure at announcement

\begin{tabular}{|c|c|c|c|c|c|c|c|c|}
\hline & \multicolumn{2}{|c|}{$\begin{array}{c}\text { Whole sample } \\
\text { (330 firms) }\end{array}$} & \multicolumn{2}{|c|}{$\begin{array}{l}\text { Public sellers } \\
\text { (207 firms) }\end{array}$} & \multicolumn{2}{|c|}{$\begin{array}{c}\text { Private sellers } \\
\text { (45 firms) }\end{array}$} & \multicolumn{2}{|c|}{$\begin{array}{c}\text { Residual group } \\
\text { (78 firms) }\end{array}$} \\
\hline founders/family & 198 & $60.0 \%$ & 119 & $57.5 \%$ & 29 & $64.4 \%$ & 50 & $64.1 \%$ \\
\hline $\begin{array}{l}\text { Majority-controlled by } \\
\text { another company }\end{array}$ & 44 & $13.3 \%$ & 28 & $13.5 \%$ & 8 & $17.8 \%$ & 8 & $10.3 \%$ \\
\hline $\begin{array}{l}\text { Majority-controlled by } \\
\text { other type of owner }\end{array}$ & 37 & $11.2 \%$ & 23 & $11.1 \%$ & 7 & $15.6 \%$ & 7 & $9.0 \%$ \\
\hline $\begin{array}{l}\text { No majority owner (no } \\
\text { single block }>50 \% \text { ) }\end{array}$ & 40 & $12.1 \%$ & 31 & $15.0 \%$ & 1 & $2.2 \%$ & 8 & $10.3 \%$ \\
\hline Missing & 11 & $3.3 \%$ & 6 & $2.9 \%$ & 0 & $0.0 \%$ & 5 & $6.4 \%$ \\
\hline
\end{tabular}

The table reports the frequency of ownership characteristics at the time of the IPO announcement. Ownership data come from newspaper sources, annual reports, and IPO prospectuses, and are both supplemented and cross-checked with standard sources such as Commerzbank's Wer gehört zu wem? and various Hoppenstedt's publications (Handbuch der Aktiengesellschaften, Handbuch der Großunternehmen, and Handbuch der mittelständischen Unternehmen). Ownership data are available for 319 firms. We concentrate on stakes of at least $25 \%$, as disclosure of smaller stakes is not mandatory. Each cell contains the number and proportion of firms with the respective ownership structure. 'Other type of owner' includes the government and financial institutions. 
Table 6. Performance and profitability after the IPO announcement

\begin{tabular}{|c|c|c|c|c|c|}
\hline & Year & $\begin{array}{c}\text { Whole } \\
\text { sample } \\
\text { (330 firms) }\end{array}$ & $\begin{array}{c}\text { Public } \\
\text { sellers } \\
\text { (207 firms) } \\
\end{array}$ & $\begin{array}{c}\text { Private } \\
\text { sellers } \\
\text { (45 firms) }\end{array}$ & $\begin{array}{c}\text { Residual } \\
\text { group } \\
\text { (78 firms) }\end{array}$ \\
\hline \multicolumn{6}{|l|}{ Sales and earnings levels } \\
\hline \multirow[t]{4}{*}{ Sales (DEM m) } & 0 & 224.9 & 204.6 & 188.3 & 288.0 \\
\hline & 1 & 247.8 & 231.6 & 174.3 & 384.2 \\
\hline & 2 & 264.8 & 241.8 & 296.7 & 384.2 \\
\hline & 3 & 264.8 & 243.6 & 256.9 & 343.9 \\
\hline \multirow[t]{4}{*}{ Earnings (DEM m) } & 0 & 7.3 & 7.8 & 4.2 & 7.2 \\
\hline & 1 & 6.6 & 7.7 & 4.5 & 8.1 \\
\hline & 2 & 6.2 & 7.5 & 4.3 & 4.3 \\
\hline & 3 & 7.5 & 7.7 & 4.2 & 9.6 \\
\hline \multicolumn{6}{|l|}{ Performance } \\
\hline \multirow[t]{4}{*}{ Industry-adjusted sales growth (\%) } & {$[-1 ; 0]$} & $16.3^{* * *}$ & $17.5^{* * *}$ & $23.4^{* * *}$ & $9.4^{* * * *}$ \\
\hline & {$[0 ;+1]$} & $17.9^{* * * *}$ & $19.4^{* * *}$ & $9.3^{* * *}$ & $17.2^{* * *}$ \\
\hline & {$[+1 ;+2]$} & $11.8^{* * *}$ & $13.2^{* * *}$ & $5.7^{* * *}$ & $5.0^{* *}$ \\
\hline & {$[+2 ;+3]$} & $9.5^{* * *}$ & $10.8^{* * *}$ & 2.7 & 5.0 \\
\hline \multirow[t]{4}{*}{ Industry-adjusted earnings growth (\%) } & {$[-1 ; 0]$} & $10.1^{* * *}$ & $14.9^{* * *}$ & -6.8 & -28.8 \\
\hline & {$[0 ;+1]$} & $28.2^{* * *}$ & $28.5^{* * *}$ & 10.8 & 14.1 \\
\hline & {$[+1 ;+2]$} & 9.6 & $11.1^{* *}$ & -7.4 & -13.3 \\
\hline & {$[+2 ;+3]$} & $11.6^{* * *}$ & $11.8^{* * * *}$ & 3.2 & 8.2 \\
\hline \multicolumn{6}{|l|}{ Profitability } \\
\hline \multirow{4}{*}{ Industry-adjusted return on sales (\%) } & 0 & $1.4^{* * * *}$ & $1.7^{* * *}$ & -0.1 & $0.8^{* * * *}$ \\
\hline & 1 & $0.9^{* * * *}$ & $1.3^{* * *}$ & -0.7 & -0.1 \\
\hline & 2 & $0.9^{* * * *}$ & $1.2^{* * * *}$ & -0.7 & -0.9 \\
\hline & 3 & $0.7^{* * *}$ & $0.9^{* * * *}$ & -1.0 & 0.7 \\
\hline
\end{tabular}

The sample consists of 330 firms that announced their intention to go public in Germany between 1984 and 1995 . Public sellers are firms that by December 1999 had gone on to raise public equity by floating on a stock exchange. Private sellers are firms that raised equity from private sources instead. The residual group contains firms that either had gone bankrupt or are right-censored in the sense that we do not track them for long enough to observe their final choices. The table reports certain firm characteristics that may be interpreted as value drivers: sales and earnings levels and growth rates as measures of performance, and return on sales (ROS) as a measure of profitability. Sales and earnings levels are deflated to 1991 purchasing power using the GDP deflator. Growth in sales and earnings is adjusted for industry trends, by subtracting the corresponding growth rate for the median German firm in the same industry as the IPO candidate. ROS is similarly adjusted by subtracting the corresponding ROS for the median German firm in the same industry. The data underlying the industry adjustments come from Worldscope. For each of these variables, we report the median for the fiscal year in which the announcement took place (year 0) as well as the following three years. For all industry-adjusted variables, we test whether the median equals zero using a Wilcoxon signed-rank test. We use ${ }^{* * * * *}$, and ${ }^{*}$ to indicate significance at the $1 \%, 5 \%$, and $10 \%$ level, respectively. 
Table 7. Hazard models

\begin{tabular}{|c|c|c|c|c|}
\hline & $\begin{array}{c}\text { Time- } \\
\text { varying? }\end{array}$ & $\begin{array}{c}\text { Complete } \\
\text { IPO? } \\
(1) \\
\end{array}$ & $\begin{array}{l}\text { Raise outside } \\
\text { equity? } \\
\text { (2) }\end{array}$ & $\begin{array}{c}\text { Raise equ } \\
\text { privately } \\
(3)\end{array}$ \\
\hline \multicolumn{5}{|l|}{ Firm-level value drivers } \\
\hline \multirow[t]{3}{*}{ industry-adjusted sales growth } & Yes & $0.426^{* *}$ & $0.299^{*}$ & -0.443 \\
\hline & & 0.281 & 0.234 & 0.289 \\
\hline & & [1.531] & {$[1.348]$} & {$[0.642]$} \\
\hline \multirow[t]{3}{*}{ industry-adjusted earnings growth } & Yes & $0.105^{* *}$ & $0.083^{*}$ & -0.026 \\
\hline & & 0.055 & 0.051 & 0.080 \\
\hline & & [1.110] & [1.087] & [0.974] \\
\hline \multirow[t]{3}{*}{ industry-adjusted return on sales (\%) } & Yes & $0.023^{* *}$ & $0.020^{* *}$ & -0.024 \\
\hline & & 0.009 & 0.009 & 0.027 \\
\hline & & [1.023] & {$[1.020]$} & {$[0.976]$} \\
\hline \multirow[t]{3}{*}{$=1$ if intend to sell secondary shares } & No & $-0.324^{* *}$ & $-0.272^{* *}$ & -0.006 \\
\hline & & 0.111 & 0.105 & 0.355 \\
\hline & & [0.724] & {$[0.762]$} & [0.994] \\
\hline \multicolumn{5}{|c|}{ Market conditions and investment opportunities } \\
\hline \multirow[t]{3}{*}{ median industry market-to-book ratio } & Yes & -0.052 & -0.101 & 0.029 \\
\hline & & 0.109 & 0.111 & 0.267 \\
\hline & & {$[0.950]$} & [0.904] & [1.029] \\
\hline \multirow[t]{3}{*}{ industry index return (\%) } & Yes & $0.024^{* * *}$ & $0.019^{* * *}$ & -0.012 \\
\hline & & 0.008 & 0.007 & 0.012 \\
\hline & & {$[1.025]$} & [1.019] & {$[0.988]$} \\
\hline \multicolumn{5}{|l|}{ Uncertainty about future profitability } \\
\hline \multirow[t]{3}{*}{ log age at time of IPO announcement } & No & 0.071 & 0.045 & -0.051 \\
\hline & & 0.050 & 0.042 & 0.087 \\
\hline & & {$[1.074]$} & [1.046] & {$[0.950]$} \\
\hline \multirow[t]{3}{*}{ industry index volatility (\%) } & Yes & 0.291 & 0.169 & -0.599 \\
\hline & & 0.263 & 0.208 & 0.300 \\
\hline & & {$[1.338]$} & {$[1.184]$} & [0.549] \\
\hline \multicolumn{5}{|l|}{ Private benefits } \\
\hline \multirow[t]{3}{*}{$=1$ if family firm } & No & $-0.301^{* *}$ & $-0.254^{* *}$ & -0.135 \\
\hline & & 0.107 & 0.100 & 0.407 \\
\hline & & {$[0.740]$} & {$[0.775]$} & {$[0.874]$} \\
\hline
\end{tabular}

Continued over 
Table 7. Hazard models, continued

\begin{tabular}{|c|c|c|c|c|}
\hline & $\begin{array}{c}\text { Time- } \\
\text { varying? }\end{array}$ & $\begin{array}{l}\text { Complete } \\
\text { IPO? } \\
(1)\end{array}$ & $\begin{array}{l}\text { Raise outside } \\
\text { equity? } \\
\text { (2) } \\
\end{array}$ & $\begin{array}{c}\text { Raise equity } \\
\text { privately? } \\
\text { (3) } \\
\end{array}$ \\
\hline \multicolumn{5}{|l|}{ Macroeconomic conditions } \\
\hline \multirow[t]{3}{*}{ consumer confidence index } & Yes & $0.033^{* * *}$ & $0.043^{* * *}$ & $0.075^{* *}$ \\
\hline & & 0.012 & 0.011 & 0.032 \\
\hline & & {$[1.034]$} & {$[1.044]$} & {$[1.077]$} \\
\hline \multicolumn{5}{|l|}{ Conditions in debt and IPO markets } \\
\hline \multirow[t]{3}{*}{ corporate bond yield premium over FIBOR (\%) } & Yes & 0.081 & -0.001 & $-0.328^{*}$ \\
\hline & & 0.083 & 0.067 & 0.125 \\
\hline & & [1.084] & [0.999] & {$[0.721]$} \\
\hline \multirow[t]{3}{*}{ trailing average four-quarter IPO initial return (\%) } & Yes & 0.003 & 0.000 & -0.010 \\
\hline & & 0.005 & 0.004 & 0.012 \\
\hline & & [1.003] & {$[1.000]$} & {$[0.990]$} \\
\hline \multirow[t]{3}{*}{$\log$ number of IPOs } & Yes & $-0.317^{* * *}$ & $-0.308^{* * *}$ & -0.094 \\
\hline & & 0.072 & 0.064 & 0.182 \\
\hline & & {$[0.728]$} & {$[0.735]$} & {$[0.911]$} \\
\hline \multicolumn{5}{|l|}{ Diagnostics } \\
\hline Wald test: all coefficients $=0\left(\chi^{2}\right)$ & & $90.9^{* * *}$ & $83.4^{* * *}$ & 25.5 \\
\hline Number of observations (time at risk) & & 2,883 & 2,883 & 2,883 \\
\hline Number of firms & & 303 & 303 & 303 \\
\hline Number of exits & & 204 & 244 & 40 \\
\hline
\end{tabular}

We estimate Cox (1972) models of the likelihood $h_{i}(t)=h_{0}(t) \exp \left(x_{i t} \beta\right)$ that a firm $i$ with characteristics $x_{i t}$ will go public (column 1), raise outside equity either publicly or privately (column 2), or raise equity from private sources (column 3), in the next instance $\Delta t$. Firms not observed to make these choices by December 1999 are treated as right-censored. The covariates, listed in the table, are defined as in Tables 3 through 5 and Figures $2 \mathrm{a}$ through $2 \mathrm{~g}$. The models also include industry fixed effects (not shown to conserve space). The covariates are mostly timevarying, in the sense that they take different values as time progresses. Time-varying variables are observed quarterly except for the accounting variables and market-to-book ratios, which are observed annually. The sample consists of 330 firms that announced their intention to go public in Germany between 1984 and 1995. The sample size drops from 330 to 303 firms due to missing data on company age and family ownership and because we exclude eight firms that went bankrupt. (Including them instead leads to lower standard errors, so the results reported in this table are conservative in this respect.) Robust standard errors, reported in italics underneath the coefficient estimates, are adjusted for heteroskedasticity by clustering on firm name (that is, the various quarterly observations between announcement and final exit for a given firm are not assumed to be independent). We use $* * * * *$, and ${ }^{*}$ to indicate significance at the $1 \%, 5 \%$, and $10 \%$ level, respectively. Hazard ratios (exponentiated coefficients) are shown in brackets underneath the coefficient estimates. The hazard ratio gives an estimate of how much the hazard of the event increases for a unit change in the covariate. For instance, a hazard ratio of 0.74 for family firms means that such firms are only $74 \%$ as likely to go public as other firms. 